$1 / 2.24-9.38 .501$

$\checkmark$

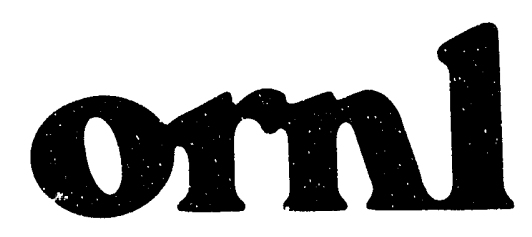

ORNL/Sub/86-22044/2

\section{OAK RIDGE NATIONAL LABORATORY}

Makron makisaria
Development Of A Zirconia-Mullite Based Ceramic For Recuperator Applications

J. M. Gonazlez

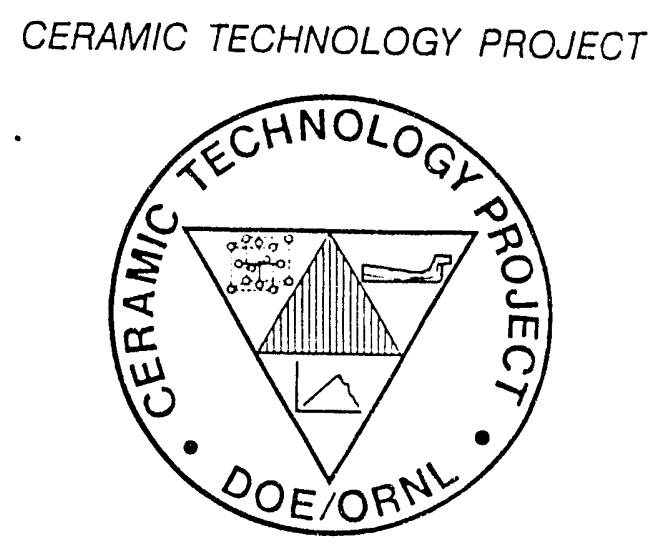

MANAGED BY

MARTIN MARIETTA ENERGY SYSTEMS, INC.

FOR THE UNITED STATES

DEPARTMENT OF ENERGY 
This report has been reproduced directly from the best Elvailable copy.

Available to DOE and DOE contractors from the Office of Scientific and Technical Information, P.O. Box 62, Oak Ridge, TN 37831 ; prices available from (615) 576-8401, FTS 626-8401.

This report was prepared as an account of work sponsored by an agency of the United States Government. Neither the United States Government nor any agency thereof, nor any of their employees, makes any warranty, express or implied, or assumes any legal liability or responsibility for the accuracy, completeness, or usefulness of any information, apparatus, product, or process disclosed, or represents that its use would not infringe privately owned rights. Reference herein to any specific commercial product, process, or service by trade name, trademark, manufacturer, or otherwise, does not necessarily constitute or imply its endorsement, recommendation, or favoring by the United States Government or any agency thereof. The views and opinions of authors expressed herein do not necessarily state or reflect those of the United States Government or any agency thereof. 


\section{DEVELOPMENT OF A ZIRCONIA-MULLITE}

\section{BASED CERAMIC FOR RECUPERATOR APPLICATIONS}

Subcontract No. $86 \times 22044 C$

Jeffery M. Gonzalez

GTE Products Corporation

Towanda, PA

Date PublishedDecember 1992

Prepared for the

DOE Office of Industrial Technologies

ED 0402000

Prepared by the

OAK RIDGE NATIONAL LABORATORY

Oak Ridge, Tennessee 37831-6285

managed by

MARTIN MARIETTA ENERGY SYSTEMS, INC.

for the

U.S. DEPARTMENT OF ENERGY

under Contract DE-AC05-84OR21400 
TABLE OF CONTENTS

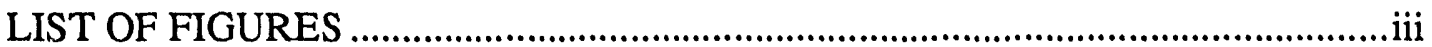

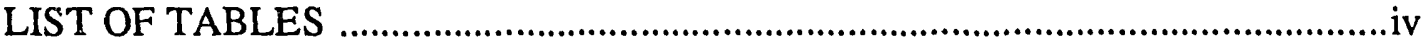

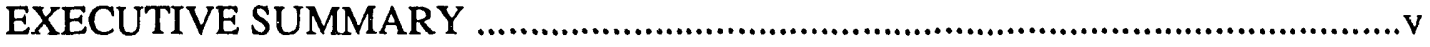

ABSTRACT

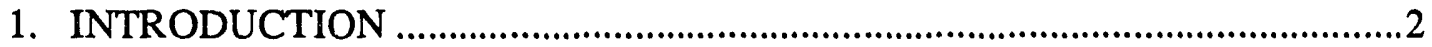

1.1 The GTE Recuperator System Design …................................................

1.2 Industrial Operating Experience Summary .............................................5

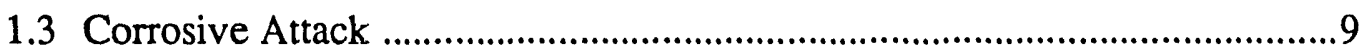

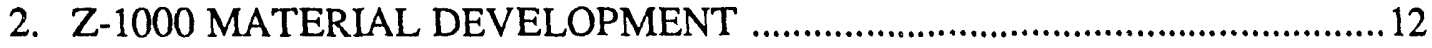

2.1 Corrosion Resistant Coatings of Z-1000 ................................................. 12

2.2 Z-1000 Extrusion Process Development ..................................................26

2.2.1 Summary of MAS-8400 Manufacturing Process .............................26

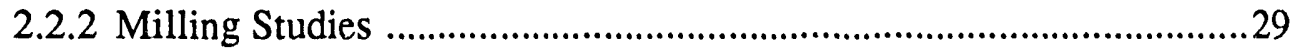

2.2.3 Compounding and Extrusion Studies ...............................................31

2.2.4 Binder Removal and Sintering of Z-1000 .......................................37

2.2.5 Crossflow Recuperator Design for Z-1000 Material .........................45

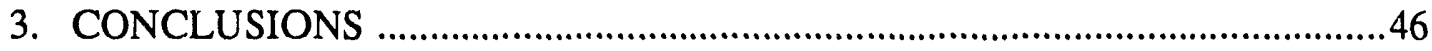

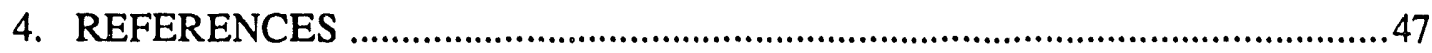




\section{LIST OF FIGURES}

Figure 1 GTE Ceramic Recuperator Matrix .......................................................4

Figure 2 Housed GTE Recuperator with Cutaway Section ...................................6

Figure 3 Typical Thermal Performance of GTE Ceramic Recuperator ....................7

Figure 4 GTE Ceramic Recuperator Flow Arrangement ...................................... 13

Figure 5 GTE R1500 "Solid Edge" Ceramic Recuperator after exposure to 400 grams of $\mathrm{NaOH}$ for $8 \mathrm{~h} @ 2450^{\circ} \mathrm{F}$.........................15

Figure 6 GTE R1500 (standard) Ceramic Recuperator after exposure to 400 grams of $\mathrm{NaOH}$ for $8 \mathrm{~h} @ 2450^{\circ} \mathrm{F}$........................ 15

Figure 7 Corrosion Test Stand .......................................................................20

Figure 8 Schematic of the Corrosion Test Stand................................................21

Figure 9 MAS - 8400 (Cordierite-Mixed-Oxide) Test Modules after exposure to $10 \mathrm{~g}$ (each) $\mathrm{NaOH}$ at $2450 \mathrm{o} \mathrm{F}$ for $6 \mathrm{~h}$

Figure 10 Uncoated MAS - 8400 (Cordierite-Mixed-Oxide) Test Module after exposure to $10 \mathrm{~g}$ (each) $\mathrm{NaOH}$ at $2450^{\circ} \mathrm{F}$ for $6 \mathrm{~h}$ .22

Figure 11 Uncoated MAS - 8400 (Cordierite-Mixed-Oxide) Test Module (Left) and MAS- 8400 module coated with Zirmul-361 and 15\% Talc $\left(2777^{\circ} \mathrm{F}\right.$ ) after exposure to $10 \mathrm{~g}$ (each) $\mathrm{NaOH}$ at $2450^{\circ} \mathrm{F}$ for $6 \mathrm{~h} . .24$

Figure 12 Uncoated MAS - 8400 (Cordierite-Mixed-Oxide) Test Module (Left) and MAS-8400 module coated with Zirmul-361 and 15\% Talc $\left(2777^{\circ} \mathrm{F}\right.$ ) after exposure to $10 \mathrm{~g}$ (each) $\mathrm{PbO}$ at $2450^{\circ} \mathrm{F}$ for $6 \mathrm{~h} . . . .24$

Figure 13 Not Available

Figure 14 Extrusion dies for Extrusion of plate/fin sheets of Ceramic .27

Figure 15 Assembly Illustration for GTE Ceramic Crossflow Recuperator .............28

Figure 16 Micrograph of Z-1000 (85\% milled Zirmul-361, 15\% Talc)

Sintered to $2777^{\circ} \mathrm{F}$, @1000X.........................................................440

Figure 17 Modulus of Rupture Loading Fixture ....................................................4. 42

Figure 18 Four Point Bend Test Loading Arrangement ........................................4.42

Figure 19 Modulus of Rupture Test Specimen .....................................................43

Figure 20 X-Ray Diffraction Patterns of Zirmul-361:Talc (85:15)

Sintered@2642, 2777, 2912 F.....

Figure 21 Segmented Recuperator Design for a Z-1000 Ceramic Matrix .45 


\section{LIST OF TABLES}

Table 1 GTE Industrial Furnaces/Recuperators .....................................................

Table 2 Recuperator Performance By Operating Range ………………............... 10

Table 3 Recuperator Performance by Size ............................................................ 10

Table 4 Corrosion tests on GTE R1500 TPX Cramic Matrix ................................14

Table 5 Corrosion tests on GTE R1500 TPX Cramic Matrix................................16

Table 6 Properties of MAS-8400, Zirmul-361 and Staywhite Talc........................30

Table 7 Ball Milling Effectiveness of Zirmul-361, A Time Study,

1 Gallon Polypropylene Jugs with $4.0 \mathrm{Kg}$ of $0.25 \mathrm{in}$.

capped $\mathrm{Al}_{2} \mathrm{O}_{3}$ Cylinders. The media:charge ratio

was $8: 1$ (by weight).

Table 8 Sweco Milling Effectiveness (model - M-18/5) of Zirmul-361,

A Time Study, 1 Gallon Lined Containers with $4.0 \mathrm{Kg}$ of 0.25 in. capped $\mathrm{Al}_{2} \mathrm{O}_{3}$ Cylinders. The media:charge ratio was $8: 1$ (by weight).

Table 9 Composition of Compounding Trials (Batch 1-6) Simpson Muller Mixer - Ribbon Extrusion Press ...............................32

Table 10 Extrusion Capability of Zirmul-361, Batch 1-6 ........................................34

Table 11 Compounding / Extrusion Designed Experiment, 16 Experiment

Fractional Factorial with 5 Variables..............................................36

Table 12 Sweco Milling of 23 Batches of Zirmul -361 ..........................................38

Table 13 Results of 16 Experiment Fractional Factorial Designed Experiment for 5 Variables, Compounding and Extrusion Study .......................39

Table 14 Properties of Z-1000 (85\% milled Zirmul-361, 15\% Talc)

Sintered to $2777 \cdot F$ .40 


\section{EXECUTI:E SUMMARY}

GTE Products Corporation, under a jointly funded program with the U.S. Department of Energy (DOE), developed a compact ceramic high temperature recuperator that could recover heat from relatively clean exhaust gases at temperatures up to of $2500^{\circ} \mathrm{F}$. The DOE program was very successful in that it allowed GTE to improve the technical and economic characteristics of the recuperator and stimulate industrial acceptance of the recuperator as an energysaving technology.

The success of the DOE Program was measured by the fact that from January 1981 to December 1984, 561 recuperators were installed by GTE on new or retrofitted furnaces. One objective of this contract was to conduct a telephone survey of the industrial plants that use the recuperator to determine their operating experience, present status, and common problems, and thus to complete the historical picture.

The ceramic matrix material is made of cordierite, a magnesium aluminum silicate, in 10 in. cubes, 12-in. cubes, and 12- x 12-x 18-in. units that are rated at 0.6,1.0, and 1.5 million $\mathrm{Btu} / \mathrm{h}$ respectively. The exhaust gases from the furnace flow straight through the recuperator, while the air to be heated makes three passes. This arrangement allows air to be heated to $1300^{\circ} \mathrm{F}$ with exhaust gas temperatures of $2400^{\circ} \mathrm{F}$. The three pass arrangement is counterflow with respect to the exhaust flow path. The design helps minimize temperature-induced stresses in the cordierite material, thus improving the reliability of the unit.

The thrust of the marketing effort was in the metal processing industries. This focus appears to be correct in view of the energy consumption and number of furnaces in these industries. The durability of the recuperators is indicated by their survival rate. Among 561 units installed on 165 new or retrofitted furnaces in 89 plants, 405 units (72\%) were operating after 4 years. There are 117 units $(21 \%)$ that are not in use either because of failure, poor business climate, or plant shutdown. The combined energy saving of the present operating units is estimated to be about $0.5 \times 10^{12} \mathrm{Btu} /$ year.

The reliability of the recuperated furnace is high in the lower temperature applications. Most of the recuperators (87\%) installed on furnaces operating at $2000^{\circ} \mathrm{F}$ and below were operational through June 1988 , while only $57 \%$ were being used on furnaces operating above $2000^{\circ} \mathrm{F}$. Regarding recuperator size, the smallest unit seems to be more reliable. Of the three sizes of recuperators installed, $89 \%$ of the small 10 -in.cubes, $72 \%$ of the intermediate 12 -in. cubes and only $56 \%$ of the large units were operational. Possibly the large units are more severely stressed during operation or flaws may develop during the fabrication process.

The initial problems with hot air burners and combustion controls were solved by GTE 
and the burner manufacturers. The current problems are recuperator plugging and corrosive attack by alkali compounds, both of which depend on the specific application. In most cases, plugged recuperators could be cleaned with an air lance during normal shutdown and reused. The alkali compounds appear to form lower temperature eutectics with the cordierite material, and if the furnace operating temperatures exceeded the softening point of the eutectic, failure occurred.

Sources of alkali compounds are fluxes used in aluminum remelt furnaces or pottery kilns, topping compounds used on steel ingots, and effluents from organic materials (trace concentrations) generated over extended periods of operation (16,000 hours). Task 1 of this study (reported in ref.\#3) confirmed the effect of temperature on the life cycle of the recuperator. At temperatures above $2150^{\circ} \mathrm{F}$ life cycles can be reduced to weeks if the concentration of a reactive contaminant is high. Designs must reduce the alkali concentration (process modification), and/ or reduce the exhaust inlet temperature below $2100^{\circ} \mathrm{F}$. Injection of a sufficient quantity of ambient air into the exhaust gas stream before it enters the recuperator is one method utilized to maximize the life cycle of the ceramic. The reduced exhaust inlet temperature reduces the reaction rate of the contaminant. The recuperator efficiency is reduced only nominally. The decrease in exhaust inlet temperature and the increase in mass flow rate balance each other, resulting in negligible loss in preheat air temperature. The exhaust gas-flow inducement device (eductor) can generally accommodate the increased volume of exhaust gases, usually less thari $10 \%$. A combustion system designer must include ceramic matrix replacement costs based upon reduced life cycles into a projects economic feasibility analysis. Since there is no easy solution to alkali attack, applications generating large amounts of alkali should be avoided.

About 48,000 furnaces were identified that were similar to those in the 89 plants where the recuperators were installed. Based on the industrial users experience with this recuperator, the following industries are potential markets: metal heat treating, aluminum foundries, steel mills, steel forging, and structural clay products. Because of contaminated exhaust gas streams, the following applications should be avoided: tunnel kilns in the pottery and related industries, ladle preheaters in the ferrous and nonferrous industries, remelt and kettle furnaces in the secondary nonferrous industries and reheat/forge furnaces processing steel ingots with topping compounds.

This study investigated a series of zirconia-mullite based mixed -oxide ceramic materials. This family of ceramic materials have been used in borosilicate glass tanks successfully, and was shown to offer potential during a previous contract effort, ("Ceramic Heat Recuperators for Industrial Heat Recovery")! A corrosion test furnace was used to determine the potential for a series of compositions. A series of milling trials, compounding and extrusion experiments 
weiv hen undertaken. Manufacturing techniques were based upon the desire to fabricate cross flow matrix elements similar to GTE's commercially available cordierite ceramic. Thin wall (plate-fin) extruded sheets were manufactured and sintered to 2642,2777 and $2912^{\circ} \mathrm{F}$. MOR bars were extracted from the material sintered to $2777^{\circ} \mathrm{F}$. Phase content, thermal expansion, microstructure, and pore size distribution were evaluated. The process developed is considered suitable for manufacture of crossflow matrix elements, and thin wall tubes. Corrosion resistance was not determined for monolithic shapes of the Z-1000 ceramic, however coating tests did show that the ceramic, when applied as a coating, protected cordierite (MAS-8400) ceramic matrix elements when exposed to alkali and lead @ $2450^{\circ} \mathrm{F}$. A recuperator design concept capable of exploiting monolithic Z-1000's potential corrosion resistance is summarized. 


\title{
DEVELOPMENT OF A ZIRCONIA-MULLITE BASED CERAMIC FOR RECUPERATOR APPLICATIONS*
}

\author{
Jeffrey M. Gonzalez
}

\begin{abstract}
GTE Products Corporation, under a jointly funded program with the U.S. Department of Energy (DOE), developed a compact ceramic high temperature recuperator that could recover heat from relatively clean exhaust gases at temperatures up to $2500^{\circ} \mathrm{F}$. The DOE program was very successful in that it allowed GTE to improve the technical and economic characteristics of the recuperator and stimulate industrial acceptance of the recuperator as an energy-saving technology. The success of the DOE Program was measured by the fact that from January 1981 to December 1984, 561 recuperators were installed by GTE on new or retrofitted furnaces. With over 1200 units sold commercially between 1981 and 1990, GTE has documented the effect (long and short term) of corrosive attack (from alkalies and lead). One objective of this contract was to develop Z-1000, a zirconia-mixed oxide ceramic for use in ceramic recuperator applications that are susceptible to corrosion due to this attack. The incorporation of this material into the GTE crossflow recuperator housing would entail development of extrusion technology similar to that currently used by GTE for their cordierite-mixed-oxide z ceramic recuperator system. The first and second pass of the ceramic recuperator would utilize the current cordierite-mixed-oxide ceramic. A Z-1000 matrix element would be used in the preheated air side's third pass (the exhaust inlet section). Thermal stresses on the Z-1000 cross flow module could be minimized by selecting appropriate heat transfer surface areas for each pass. A large surface area for the first and second pass (cordierite section) could provide for sufficient heat transfer to achieve $50 \%$ effectiveness. A surface area that generates minimal heat transfer in the third pass (Z-1000) section is envisioned. The heat transferred in this section reduces the differential temperature across the matrix, and therefore thermally induced stresses are minimized. Reduced heat transfer in this section means that thermal shock resistance (TSR) of the material in the third pass becomes less critical; however, its corrosion resistance must be sufficient to withstand corrosive attack. This modular design could utilize a field repairable, disposable matrix. This report concerns itself with the development of process technology for fabricating such a matrix, and a series of corrosion tests that established the potential corrosion resistance of the Z-1000 ceramic.

- Research sponsored by the Industrial Energy Efficiency Division, Office of Industrial Technologies, U.S. Department of Energy.
\end{abstract}




\section{INTRODUCTION}

GTE Products Corporation began development of ceramic heat exchangers in 1973. This activity resulted in a high-temperature compact cross-flow recuperator made of cordierite which functions well in relatively clean exhaust gases at temperatures up to $2500^{\circ} \mathrm{F}$. Part of the development work, which was jointly funded by DOE and GTE under Contract EX-76-C01-2612 began in October 1976. A final report ${ }^{1}$ published by DOE in August 1980 described development and field testing.

In August 1980, the DOE and GTE started a cooperative program tilled a Technology Acceleration Program for High Temperature Recuperators (TAPHTR) ${ }^{2}$. The primary goals of the cooperative agreement were to test, install, and collect baseline and operating data for 175 industrial applications of the high-temperature recuperator. The specific tasks of that program were to accurately assess the industrial high-temperature process requirements; to improve the technical and economic characteristics of the recuperator; to stimulate the industrial acceptance of the recuperator for waste heat recovery; and, by saving energy and increasing productivity, to further DOE's Office of Industrial Programs industrial conservation efforts.

During the TAPHTR program, 175 recuperators were installed on 38 furnaces in 30 industrial plants. With the exception of six newly designed furnaces, the furnaces were retrofitted with recuperators. These furnaces were operated at temperatures ranging from $1600^{\circ} \mathrm{F}$ to $2500^{\circ} \mathrm{F}$ and air preheat temperatures of $700^{\circ} \mathrm{F}$ to $1300^{\circ} \mathrm{F}$ were obtained. Four furnaces were fired by \# 2 fuel oil, one by \# 4 fuel oil, and the others with natural gas. Preheated air burners were manufactured by Eclipse Inc., Hauck Manufacturing Company, North American Manufacturing Co., and Selas Corporation. The combustion control systems which regulate temperature and fuel:air ratio were modified to accommodate the preheated air from the recuperator. Pneumatic pressure control, pressure balanced mass-flow control and electronic mass-flow control systems were used.

The TAPHTR program was successful in that it provided the following benefits to the host sites:

- Fuel savings of $12 \%$ to $61 \%$ made the retrofits economically attractive.

- Productivity increases resulted because of higher product throughputs, lower furnace reheat times, and, in the case of batch furnaces, more cycles per shift.

- In some cases, materials savings resulted from decreased scale formation. 
The TAPHTR program also revealed system problems, some of which were solved during the course of the program or soon after. These were as follows:

- Inherent leakage around the seals could be tolerated provided fuel-rich conditions did not exist in the furnace.

- The initial hot air burners deposited carbon and had flame instability, but these were later corrected by the burner companies.

- Combustion controls on the cold-air side were not adequate to prevent excess gas conditions in the furnace. This was corrected after the TAPHTR program by development of a simple but novel hot-air side control system.

- In some cases, plugging of the compact recuperator passages necessitated the use of an on-line or periodic air-lance cleaning system.

- Some furnaces produce alkali or lead-based materials that can degrade the magnesium aluminum silicate (cordierite) recuperator at tempertures above $2100^{\circ} \mathrm{F}$. Many furnaces, originally categorized as producing clean exhaust, volatilize these materials as a result of the specific process or the furnace design. Degradation of the ceramic can often be eliminated or reduced by careful system design; however, experience has shown that subtle process or system design changes can produce greatly different exhaust gas constituents.

- A recuperator capable of withstanding the attack of common contaminants (alkali compounds) could accelerate the market acceptability of the ceramic heat exchanger, because a more confident estimate of life cycle could be offered for various applications.

The success of the DOE/GTE TAPHTR program is indicated by the fact that between January 1981, when the first DOE installation was started, and December 1984, about 560 recuperators sold by GTE were installed on new furnaces or were retrofitted to furnaces. Since the start of the DOE TAPHTR program, about 1200 recuperators were sold as either new or replacement units. A telephone survey was made of the industrial plants that installed the ceramic recuperator to determine their operating experience, present status, and common problems, and thus to complete the historical perspective of the recuperator. The report ${ }^{3}$ details the results of the telephone survey 
of the industrial users, provides some comparative analysis of ceramic recuperator applications, and details corrosive attack from alkalies and lead. A series of case, studies detail the mechanism of corrosive attack. This report describes a method to screen potential corrosion resistant ceramic materials, and process development activities associated with the compounding, extrusion, and densification of a zirconiamullite based ceramic.

\subsection{The GTE Recuperator System Design}

Ceramic recuperators are inanufactured in three sizes: a $10 \times 10 \times 10$ in. ceramic core with a recommended capacity of 0.6 million Btu/h, a $12 \times 12 \times 12$ in. core with a capacity of 1.0 million Btu/h and a $12 \times 12 \times 18$ in. core with a recommended capacity of 1.5 million Btu/h The ceramic cores are constructed of cordierite, a magnesium aluminum silicate (MAS), which was selected because of ease of fabrication, relatively low thermal expansion, good thermal shock resistance, and certain corrosion-resistant characteristics. The recuperator is manufaclured by bonding extruded MAS ribbed-sheets with a cordierite ceramic bonding material. The sheets and ribs are arranged to form a cross-flow heat exchanger (Figure 1). The ceramic

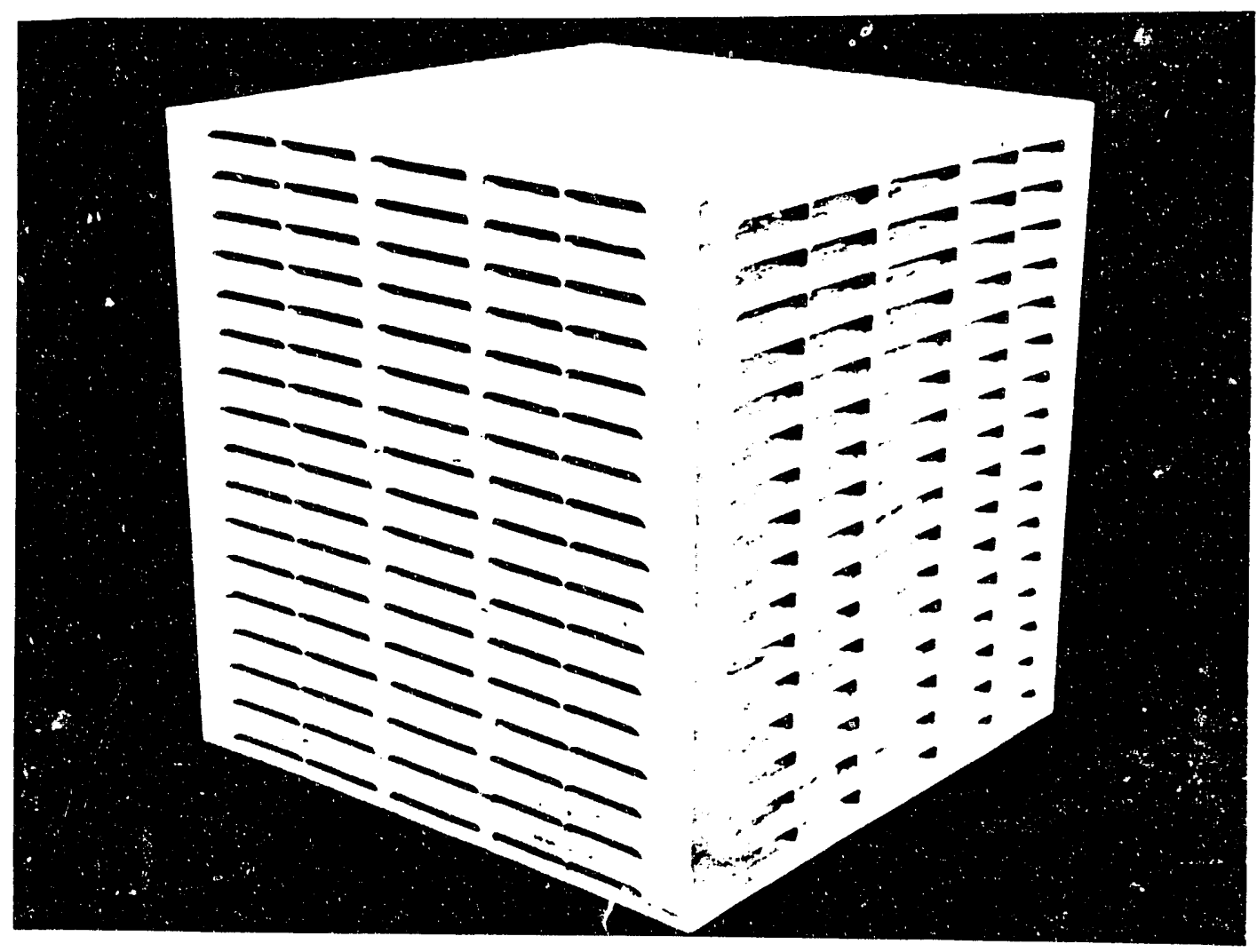

Figure 1

GTE Ceramic Recuperator Matrix 
core unit and resilient refractory seal are contained in a metallic housing. The unit is under a slight compression from a spring assembly. A key feature of current recuperators is that the preheat air makes three passes in the recuperator while the exhaust gas passes through once. The air side passes are made possible by baffles in the metal housing (Figure 2). The areas of each pass are selected to optimize the heat transfer for a given pressure drop ${ }^{4}$. Figure 3 shows the anticipated performance of a model R1000 (12 x $12 \times 12$ in.) recuperator. The triple-pass recuperator provides higher preheated air temperatures than the earlier single-pass model. An added advantage of the triple-pass recuperator is that the maximum temperature difference between the exhaust gases and the preheated air is reduced. Temperature-induced stresses are therefore lower, thus increasing the reliability of the recuperator.

Since the TAPHTR program ended in 1982, the techniques for production, firing, and encasement of the ceramic cube in the metallic housing have been improved, which have resulted in a more reliable product. Another improvement in the recuperator system is related to the method of controlling the air:fuel ratio to the burner. The common methods of mass flow control, if applied to the cold-air side, do not compensate for changes in recuperator leakage and, if applied to the hot preheated air side, do not account for variations in the preheated air temperature. In case the recuperator leaks, the cold-side control would not correct the air:fuel ratio and the furnace could run fuel rich, if the leakage was large. In the case of controls applied to the preheated air, as the preheated air temperature increases, the air:fuel ratio decreases and fuel rich conditions could result depending on the air:fuel ratio established at system calibration. In the patented GTE temperature compensator ${ }^{5}$, a bimetallic strip in the preheated air stream compensates the pressure signal which controls the fuel flow, thus preventing a fuelrich condition. This simple, relatively inexpensive device is now offered as part of the standard recuperator package.

\subsection{Industrial Operating Experience Summary}

This report is the summary of the second Task of an ORNL subcontract (N0. 86-22044). The first Task summarized the "Industrial Operating Experience of the GTE Ceramic Recuperator",7 by conducting a survey of users and a chemical analysis on recuperators that were exposed to corrosives. A listing of the furnace types and number of recuperators are presented in Table 1. Of the total 561 new recuperators, 405 or $72 \%$ are still operating and 117 are not in use at present either because of failure, poor performance, or plant shutdown. The box-type furnace used either for forging, reheating, or heat-treating metals was the most common type that GTE selected for heat recovery, accounting for $26 \%$ of the furnaces. One hundred seventy-eight recuperators were installed on these box furnaces, of which 104 or $58 \%$ 


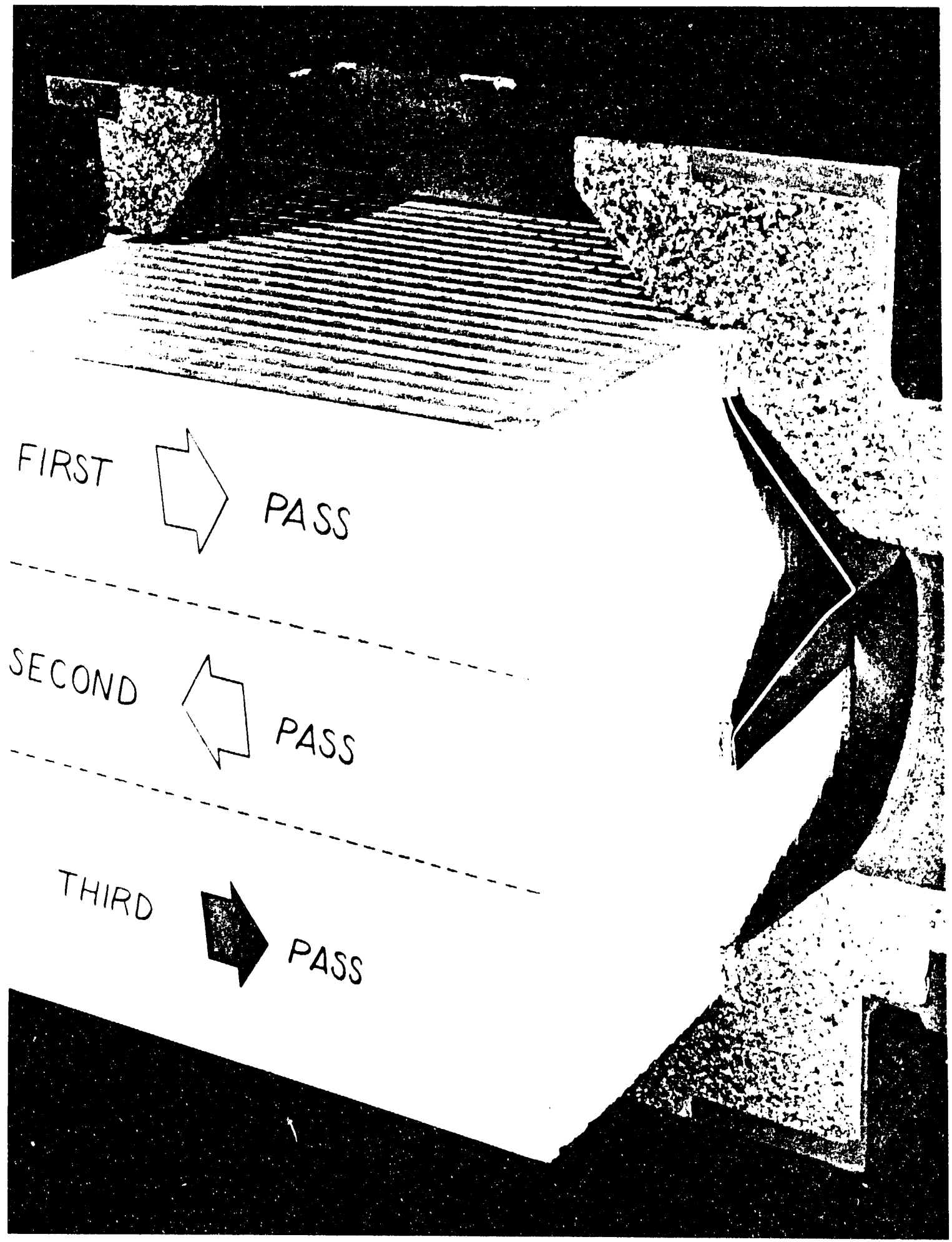

Figure 2

Housed GTE Recuperator with Cutaway Section 


\section{GTE}

R1000TPXB

- Product Code: 8163222

- Air Hole Size: .200"x x.680"

- Exhaust Hole Size: .200"x .680"

- Flow Ratio $=0.917 \pm 5 \%=\frac{\text { Air Flow }}{\text { Exhaust Flow }}$
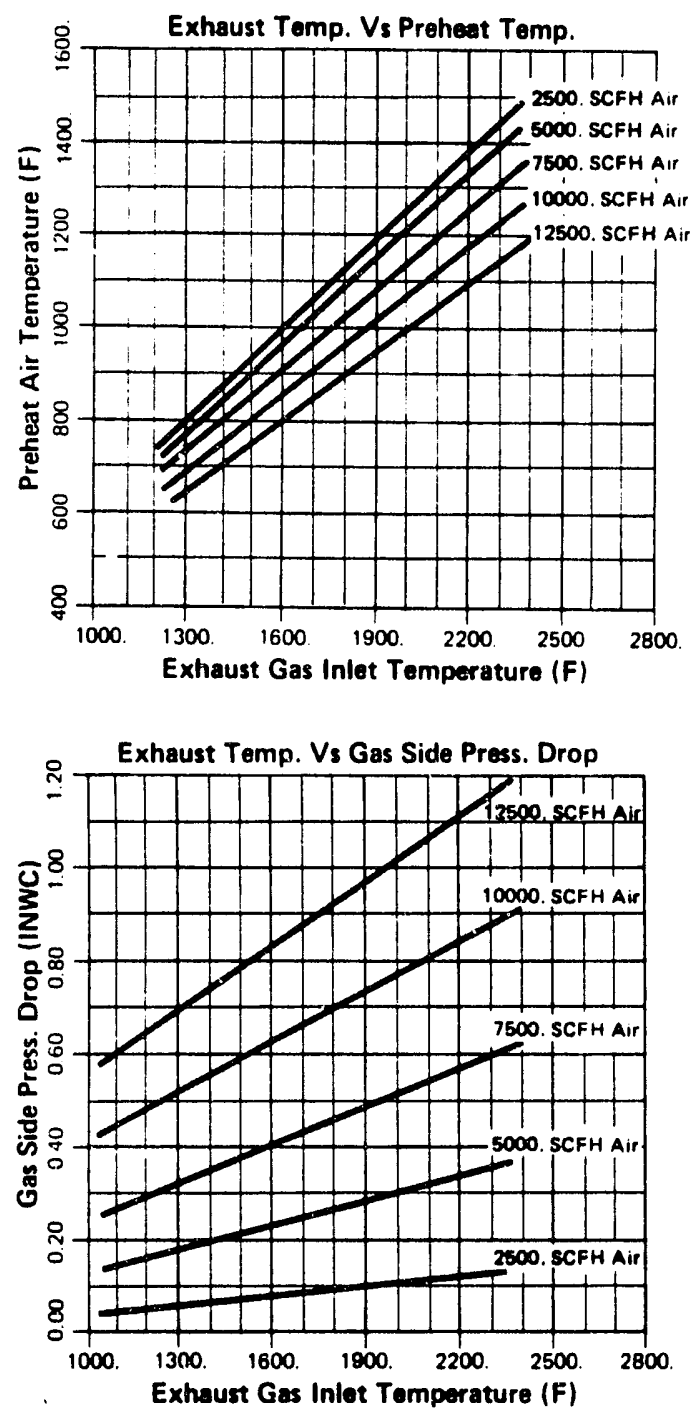

Exemple:

$1 \mathrm{~mm}$ BTU Burner using $10 \%$ excess air.

Air Flow $=11000$ SCFH

Gas Flow $=1000$ SCFH

Exhaust Flow = 12000 SCFH

Preheated Air Temp. at $2000^{\circ} \mathrm{F}$ Exhaust $=1070^{\circ} \mathrm{F}$

Pressure Drop Exhaust .87" $\mathrm{H}_{2} \mathrm{O}$ Column

Pressure Drop Air 12\%" " $\mathrm{H}_{2} \mathrm{O}$ Column
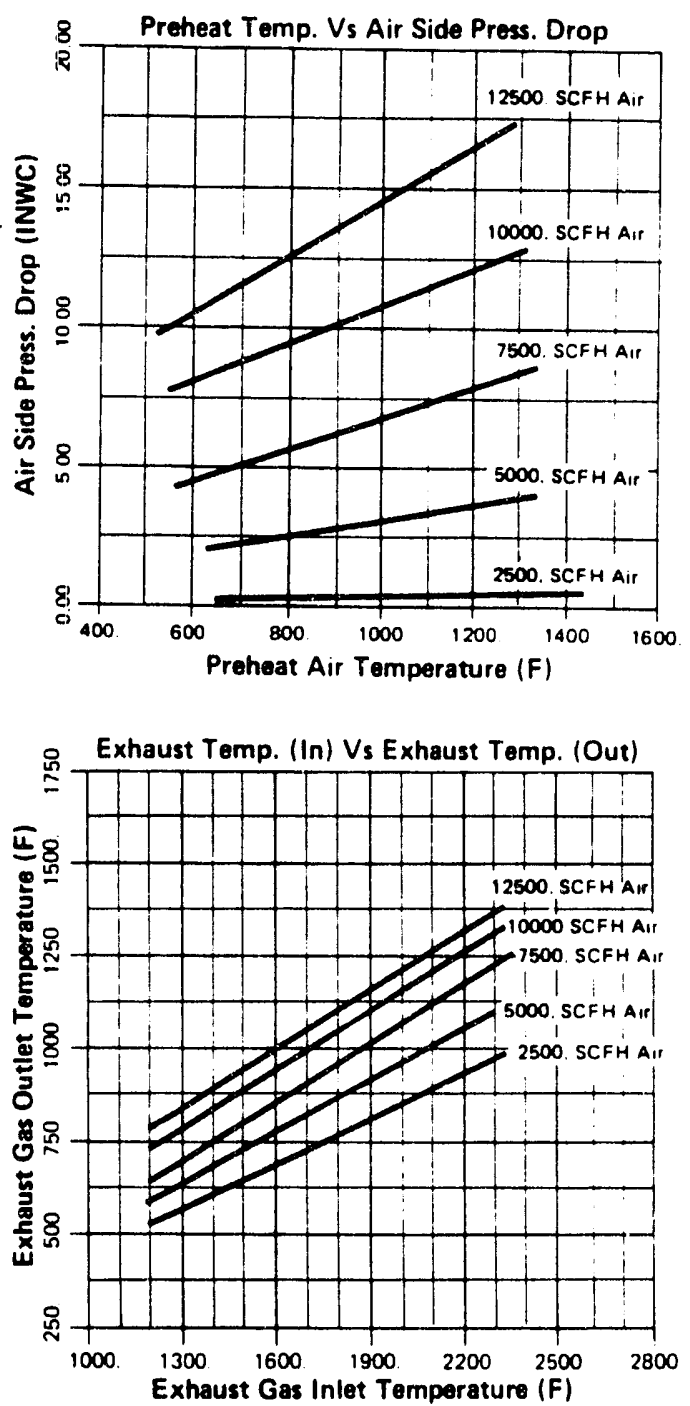

SYLVAMIA ${ }_{\text {Metals }}^{\text {Cheals }}$

Figure 3

Typical Thermal Performance of GTE Ceramic Recuperator 
Table 1

GTE Industrial Furnaces/Recuperators

\begin{tabular}{|c|c|c|c|c|c|}
\hline \multirow{2}{*}{\multicolumn{2}{|c|}{ Furnace Type }} & \multirow[b]{2}{*}{$\begin{array}{l}\text { Number of } \\
\text { Furnaces }\end{array}$} & \multicolumn{3}{|c|}{ Number of Recuperators } \\
\hline & & & Operational & $\begin{array}{l}\text { Not in } \\
\text { Use }\end{array}$ & $\begin{array}{r}\text { Status } \\
\text { Unknown }\end{array}$ \\
\hline$\overline{1}$ & Box Forge/Reheat/Heat Treat. & 43 & 104 & 61 & 13 \\
\hline 2 & Slot Forges & 18 & 17 & 22 & 0 \\
\hline 3 & Aluminum Pot Melters & 16 & 14 & 2 & 0 \\
\hline 4 & Mold/Die Reheat Furnaces & 15 & 34 & 0 & 0 \\
\hline 5 & $\begin{array}{l}\text { Indirect Tube-type Reduction } \\
\text { Furnaces }\end{array}$ & 13 & 71 & 0 & 0 \\
\hline 6 & Rotary Calciners & 9 & 29 & 0 & 0 \\
\hline 7 & Retorts & 9 & 44 & 0 & 0 \\
\hline 8 & Carbottom Forge/Heat Treat. & 7 & 43 & 8 & 12 \\
\hline 9 & Aluminum Reverberatory & 5 & 0 & 7 & 1 \\
\hline 10 & Solder Pots & 5 & 5 & 0 & 0 \\
\hline 11 & Annealing & 4 & 5 & 1 & 1 \\
\hline 12 & Muffle & 4 & 14 & 2 & 0 \\
\hline 13 & Lead Melters/Heat Treat. & 4 & 10 & 2 & 0 \\
\hline 14 & Pusher & 2 & 14 & 4 & 0 \\
\hline 15 & Rotary Hearth & 2 & 8 & 0 & 8 \\
\hline 16 & Ladle Preheaters & 2 & 0 & 2 & 0 \\
\hline 17 & Clay/Pottery Kilns & 2 & 2 & 2 & 0 \\
\hline 18 & Misc. & 5 & 1 & 4 & 4 \\
\hline & TOTALS & 165 & 405 & 117 & 39 \\
\hline
\end{tabular}


are still operational. The slot forge furnaces were the next popular category with 18 furnaces outfitted with 39 recuperators of which only $43 \%$ are in operation. None of the aluminum reverberatory furnaces or ladle preheaters are currently recuperated. However, the success rate on pot melters, tube furnaces, rotary, retorts, and heat-treating furnaces was high.

If one considered the performance of the recuperators based on their operating temperature, shown in Table 2, one finds that $87 \%$ of those installed on furnaces at $2000^{\circ} \mathrm{F}$ and below are still operating, while only $57 \%$ of those installed at temperatures above $2000^{\circ} \mathrm{F}$ are still operating. The recuperator performance based on size is shown in Table 3. GTE manufactured the recuperators in three sizes, $0.6,1.0$, and 1.5 million Btu/h and these are $10 \times 10 \times 10 \mathrm{in}$., $12 \times 12 \times 12$ in., and $12 \times 12 \times 18$ in., respectively. Eighty-nine percent of the small units are still operating, while $77 \%$ of the medium size units are operational and only $56 \%$ of the larger units are still operating.

\subsection{Corrosive Attack}

One application that GTE has concentrated on is alloy steel forging furnaces. These are mostly box-type furnaces that operate at between $2250^{\circ} \mathrm{F}$ and $2350^{\circ} \mathrm{F}$ depending on the type of alloy being worked. Most of the furnaces were natural gas fired and the exhaust gases were expected to be clean. However, at ten facilities problems arose with the leaking recuperators causing the preheat air temperatures to drop. As the leaks got gradually worse, the furnaces would run fuel-rich and then the recuperators rapidly deteriorated. In the beginning, it was thought that the recuperators may have been faulty or that the furnace operators had run the furnace at fuel-rich conditions, causing the recuperators to crack. What was puzzling was that there were several plants where similar box forge furnaces were operating satisfactorily with the same fuel and at the same temperatures. Initially, the problem recuperators were replaced, but replaced matrices soon suffered the same fate.

GTE analyzed several of the failed recuperators in the laboratory and found traces of sodium and potassium. The source of the sodium and potassium was traced to the ingots that were processed through the furnace. All of the furnaces at the ten plants processed raw ingots either continuously or on occasion. When raw steel is poured into an ingot, salts of sodium, potassium, calcium, etc., are placed on the top of the ingot. These are referred to as topping compounds. When these raw ingots are reheated in the recuperated furnace, the alkali deposits in the cordierite matrix and corrosive attack begins. The alkali metals form lower temperature eutectics with cordierite resulting in softening and cracking of the matrix. Scott Forge, a large progressive forge shop outside Chicago, installed five sets of the GTE recuperators on one of their forge furnaces, all of which failed. They sent a failed matrix to an independent laboratory and found that $2100^{\circ} \mathrm{F}$ eutectics were formed. With exhaust gases at $2350^{\circ} \mathrm{F}$, it is easy to 
Table 2

Recuperator Performance By Operating Range

\begin{tabular}{|c|c|c|c|}
\hline & $\geq 2000^{\circ} \mathrm{F}$ & $\leq 2000^{\circ} \mathrm{F}$ & Totals \\
\hline Operating & 155 & 250 & 405 \\
\hline Not in Use & 93 & 24 & 117 \\
\hline Unknown & 25 & 14 & 39 \\
\hline Totals & 273 & 288 & 56 \\
\hline
\end{tabular}

Table 3

Recuperator Performance by Size

\begin{tabular}{lcccc}
\hline Size MM Btu/h & $\mathbf{0 . 6}$ & $\mathbf{1 . 0}$ & $\mathbf{1 . 5}$ & Totals \\
\hline Operating & 180 & 90 & 135 & 405 \\
Not in Use & 6 & 19 & 92 & 117 \\
Unknown & 17 & 7 & 15 & 39 \\
\hline Totals & $\mathbf{2 0 3}$ & $\mathbf{1 1 6}$ & $\mathbf{2 4 2}$ & $\mathbf{5 6 1}$ \\
\hline
\end{tabular}


understand why the recuperators failed. Scott Forge installed 6 sets of Hague International's Sic tubular recuperators on a furnace, all of which failed due to alkali attack. Because of their interest in conservation, they then installed Hotworks metalic units and all four failed relatively quickly. They concluded that it was not economical to recuperate furnaces that processed raw ingots containing topping compounds.

Several of the forge shops tried cutting off the tops of these ingots but could not completely get rid of the alkali metals, and the cordierite matrix failed. One plant that is satisfied with their fuel savings but would like longer recuperator life is Hawker Siddeley in Nova Scotia, Canada. This plant is supplied with hot ingots shipped in insulated containers, therefore they are unable to cut off the tops. Their furnaces are oil-fired and their paybacks (with 50\% savings) are less than a year. Their engineer would continue to replace the failed cubes as long as it was economical to do so. In the case of Cape Ann Forge, the plant is located by the seashore and sait in the air may have further contributed to the cube failure.

McWilliams Forge operates a box forge to reheat copper for forging into aircraft parts. The furnace has three recuperators. While the copper is being reheated, charcoal is thrown into the back of the furnace probably to prevent the formation of copper oxide. However, the two recuperators closest to the back of the furnace failed, and their replacements failed as well. It was found that the charcoal contained potassium which was the cause of the failure.

None of the recuperators on thealuminum remelt furnance or aluminum reverberatory furnaces are in operation because of attack by sodium. Callen Mfg. Corp. in North Lake, Illinois uses a white powder called "Smokeless Flux" for fluxing in their remelt furnace. Some of the powdur deposited in the recuperator and could not be removed by an air lance. The flux may also have contained some sodium which could have attacked the cordierite, since the exhaust gases entered the recuperator at $2200^{\circ} \mathrm{F}$. The aluminum reverberatory furnace recuperators were failures as well because of the fluxing agents used. It soon became evident that aluminum remelt/reverberatory exhaust gases are dirty gases and these applications are not suitable for the GTE recuperator.

The metal lead may also be considered a poor application with respect to attack on cordierite. Two lead melters operating at $1800^{\circ} \mathrm{F}$ were recuperated. In both cases, the recuperators plugged and were destroyed. The other two lead operations were annealing furnaces where steel spring wire and steel bailing straps are tempered. In both these plants the operations are similar although furnace temperatures are $2300^{\circ} \mathrm{F}$ and about $2000^{\circ} \mathrm{F}$ to $2100^{\circ} \mathrm{F}$, respectively. Both furnaces are still operating, but the recuperators have done better on the furnace operating at the lower temperature. Large stainless steel pots, $4 \mathrm{ft}$ wide and $12 \mathrm{ft}$ long, contain the molten lead at $1600^{\circ} \mathrm{F}$ for tempering steel and are supported at the bottom by piers 
made of firebrick. The natural gas burners fire low and the exhaust gases blow by the steel pot. Multiple straps, at least 14, and wires continuously pass through the lead. Molten lead falling on the firebrick forms a eutectic that destroys the brick rapidly. The brickwork on these furnaces is rebuilt every 6 to 12 months at American Spring Wire (ASW) but (as a rule) lasts longer at Stanley Works. Both recuperator systems are exposed to lead, but only the system with a high operational temperature (ASW) experiences shortened life cycles.

There are three distinct problems with the recuperators. First, if the lead on occasion falls into the combustion chamber, it vaporizes and deposits in the recuperator, causing some plugging. The second problem relates to the firebrick which contains some potassium and sodium that is released in firing the brick and deposits in the ceramic matrix. Regular replacement of the fire- brick would hasten the demise of the ceramic matrix. Finally, it is possible that the lead and cordierite form lower melting eutectics that may soften or crack the matrix. If lead can cause the firebrick to deteriorate that fast, it surely must have an affect on the cordierite. It is possible that the eutectics formed with lead could soften at temperatures as low as 2200 or $2300^{\circ} \mathrm{F}$. The fact that American Spring Wire operates at $2300^{\circ} \mathrm{F}$ while Stanley Works operates between 2000 and $2100^{\circ} \mathrm{F}$ may explain why the former's recuperators have to be replaced more often. It would appear that American Spring Wire should operate the furnace at a lower temperature unless this would adversely affect their production. It would appear that applications involving molten lead are not the best for the GTE recuperator.

\section{Z-1000 MATERIAL DEVELOPMENT STUDY}

GTE engineer's designed and built a corrosion test facility that simulates the corrosion that occurs during exposure of the ceramic recuperator to contaminated exhaust gases. Development of a test method required that we first understand the type of corrosion that typically destroys ceramic matrix elements. Alkalies were found to be the most prevalent contaminant identified in recuperators returned to GTE for rebuilding. The "Industrial Operating Experience of the GTE Recuperator" task of this contract effort (Reference \#3) confirmed this.

\subsection{Corrosion Resistant Coatings of Z-1000}

GTE operates a test furnace capable of testing recuperators at temperatures from 1000 $2450^{\circ} \mathrm{F}$, and flow rates from $2,000-40,000 \mathrm{scfh}$ A new refractory liner was required for the exhaust plenum area of the furnace. Prior to rebuilding the exhaust section, a series of tests was undertaken. Various amounts of sodium hydroxide $(\mathrm{NaOH})$ were vaporized under a 
R1500 (1.5 million Btu/h rating) at temperatures between 2200 and $2500^{\circ} \mathrm{F}$. A pressure of 1 psi was maintained in the preheat outlet side of the recuperator. The leakage of the recuperator was monitored. Tests were generally abandoned after combustion air flow rates could no longer maintain an outlet pressure of $1 \mathrm{psi}$. This indicated that corrosion (or melting) or a significant crack on the exhaust inlet of the recuperator had penetrated through the "dead zone" of the ceramic matrix as shown in Figure 4.

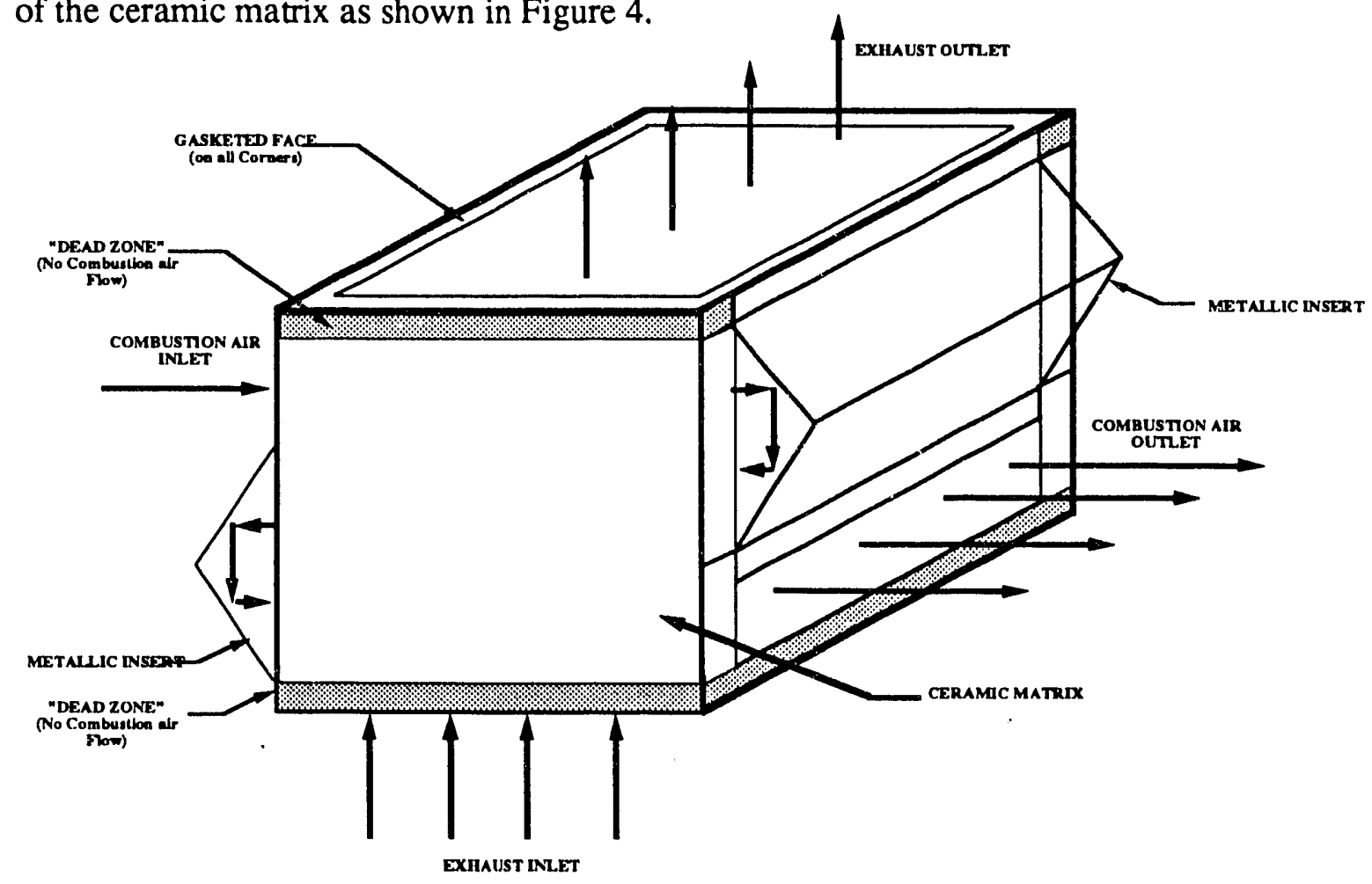

Figure 4

\section{GTE Ceramic Recuperator Flow Arrangement}

Seventeen tests were performed. A new cordierite ceramic matrix (MAS-8400) was utilized for each test. Table 4 details the type of matrix element tested, its flow configuration and type of coating evaluated (if any). Table 5 describes the operating conditions varied during each test and summarizes the leakages rates of the housed recuperator at various stages during the cycle. Our goal was the establishment of a short duration test $(<24 \mathrm{~h})$ capable of simulating the long term effects of alkali's on the ceramic matrix. Commercially available materials were screened by coating sections of the matrix, to determine their effectiveness and potential for a field test. Heat up times took less than 20 minutes, due to the low mass of the refractory fiber lining of the furnace.

The test furnace is not a closed loop, as the combustion air flow rate is independent of the flow of the exhaust air flow rate. A typical furnace operates in a closed loop. The exhaust gas 
TABLE 4

Corrosion tests on GTE R1500 TPX Cramic Matrix

\begin{tabular}{|c|c|c|c|c|}
\hline $\begin{array}{c}\text { Test } \\
\#\end{array}$ & $\begin{array}{l}\text { Recuperator } \\
\text { Model \# }\end{array}$ & $\begin{array}{l}\text { Matrix } \\
\text { Size }\end{array}$ & Configuration & $\begin{array}{c}\text { Coating Type(s) } \\
\text { Notes }\end{array}$ \\
\hline 1 & $\mathrm{R}-1500-\mathrm{TPX}-\mathrm{B}$ & $.200 \times .200$ & parallel flow TPX & none \\
\hline 2 & R-1500-TPX-B & $.200 \times .200$ & counter flow TPX & $\begin{array}{c}\text { Pyromack } 2500 \text { and } \\
\text { Cerama Preg ( in 3" sections) }\end{array}$ \\
\hline 3 & $\mathrm{R}-1500-\mathrm{TPX}-\mathrm{B}$ & $.200 \times .200$ & counter flow TPX & none \\
\hline 4 & R-1500-TPX-B & $.200 \times .200$ & counter flow TPX & ne, matrix had 56 cracks before test \\
\hline 5 & R-1500-TPX-A & $.125 \times .200$ & counter flow TPX & none \\
\hline 6 & R-1500-TPX-B & $.200 \times .200$ & counter flow TPX & pass 3 is segretated from 1 and 2 \\
\hline 7 & R-1500-TPX-B & $.200 \times .200$ & counter flow TPX & none, "solid edge" matrix \\
\hline 8 & R-1500-TPX-B & $200 \times .200$ & counter flow TPX & Zirmul-361 dip coated \\
\hline $9-10$ & R-1500-TPX-B & $200 \times .200$ & counter flow TPX & Zirmul-361 dip coated, baked on \\
\hline $11-13$ & R-1500-TPX-B & $200 \times .200$ & counter flow TPX & none \\
\hline 14 & R-1500-TPX-B & $200 \times .200$ & counter flow TPX & Zirmul on a solid edge matrix \\
\hline 15 & R-1500-TPX-B & $200 \times .200$ & counter flow TPX & MAS- 8400 with Zirmul "glue" \\
\hline 16 & $\mathrm{R}-1500-\mathrm{TPX}-\mathrm{B}$ & $200 \times .200$ & counter flow TPX & none (solid edge matrix) \\
\hline 17 & R-1500-TPX-B & $200 \times .200$ & counter flow TPX & Zirmul on a solid edge matrix \\
\hline
\end{tabular}

inlet temperature, the mass flow rate and the (mass) flow ratio all determine the thermal gradients throughout the ceramic matrix, and the mean temperature of the ceramic matrix. A flow ratio of 0.917 is achieved when a furnace is operating at $10 \%$ excess air (stoichiometry) in a closed loop manner. Combustion air can be looked at as "cooling air" for the purpose of determining its effect on chemical attack during operational conditions. As the flow ratio increases ("cooling air" flow rate), the mean temperature of the ceramic matrix decreases. A furnace that has an open slot, or an opening that allows products of combustion to escape, operates at flow ratios greater the .917 . In summary, flow ratio is defined as:

Flow Ratio $=\mathrm{Q}(\mathrm{a}) / \mathrm{Q}(\mathrm{e})$

where:

$\mathrm{Q}(\mathrm{a})=$ Flow $(\mathrm{SCFH})$ of the combustion air into the recuperator

$\mathrm{Q}(\mathrm{e})=$ Flow $(\mathrm{SCFH})$ of exhaust gases into the recuperator

$\mathrm{Q}(\mathrm{e})=$ Flow of combustion air into furnace + Flow of Natural gas into furnace

The tests described also attempted to:

- determine if reducing the mean matrix temperature could extend life cycles.

- determine the effectiveness of commercially available coatings.

- evaluate "solid edge" ceramic matrix elements.

The "solid edge" matrix is based upon a modified plate/fin sheet system. This system produces a ceramic matrix with a flat face (solid edge), as illustrated in Figure 5. The reduced 
surface area, and the fact that the refractory glue (bonding agent) is not exposed to the exhaust gases offered the potential for extended life cycles, and afforded reduced edge leakage of the ceramic matrix elements. The solid edge also provided a more consistent surface topography that facilitated improved uniformity of surface coatings. The tests did not confirm or refute life cycle enhancements based upon incorporation of the "solid edge" process. Results of the tests are listed in Table 5.

Figure 6 shows the exhaust inlet section of a recuperator exposed for 8 hours to 400 grams of $\mathrm{NaOH} @ 2450^{\circ} \mathrm{F}$. This effect is similar to those documented in reference 3.

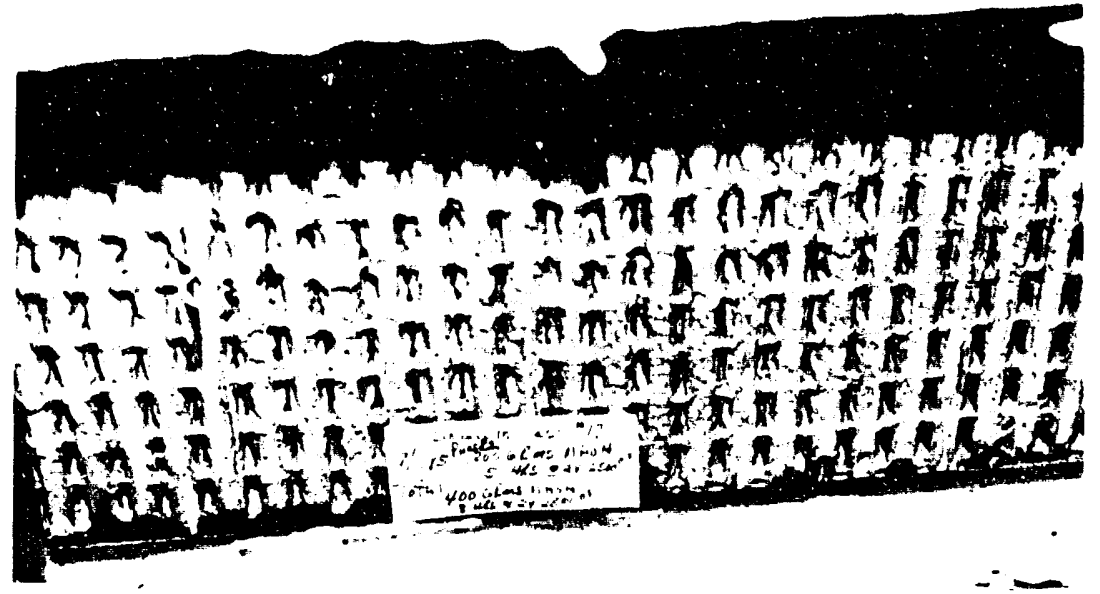

Figure 5

GTE R1500 "Solid Edge" Ceramic Recuperator after

Exposure to 400 grams of $\mathrm{NaOH}$ for $8 \mathrm{~h} @ 2450^{\circ} \mathrm{F}$

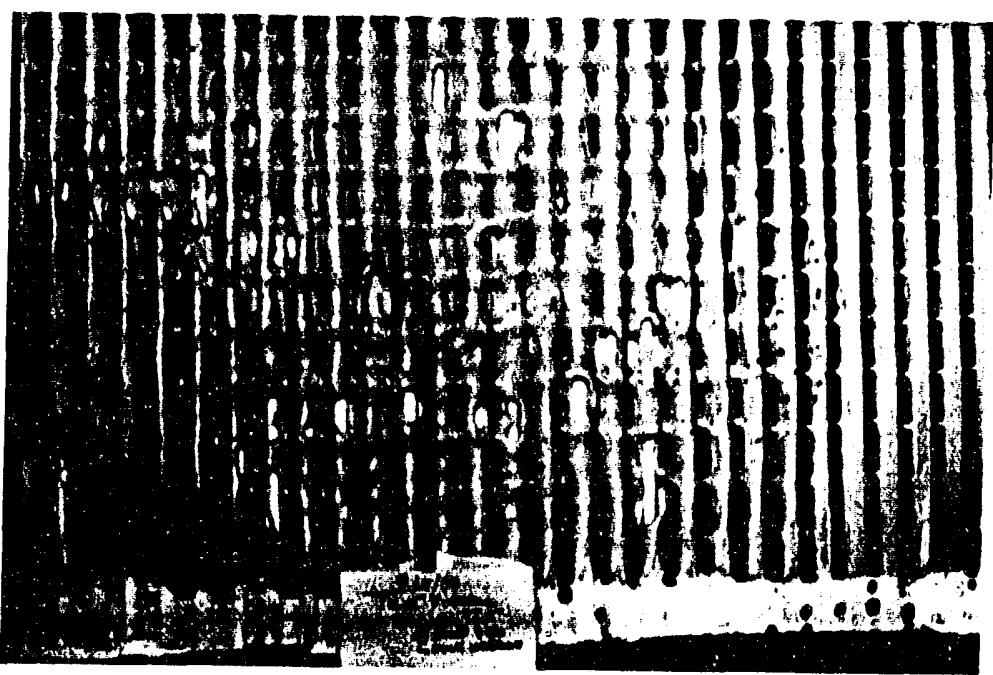

Figure 6

GTE R1500 (standard) Ceramic Recuperator after Exposure to 400 grams of $\mathrm{NaOH}$ for $8 \mathrm{~h} @ 2450^{\circ} \mathrm{F}$ 
TABLE 5

Corrosion tests on GTE R1500 TPX Cramic Matrix

Test $\mathbf{Q}$ (e) Flow Ratio Corrosive Corrosive Temp. Time Leakage Pressure

$\begin{array}{llllllll}\# & \text { SCFH } Q(a) / Q(e) & \text { Type } & \text { g } & { }^{\circ} \mathbf{F} & \text { H } & \% Q(a) & \text { osi }\end{array}$

Test 1 used a standard unit (B) with a parallel flow triple pass

$\begin{array}{lcccrrr}\text { la } & \text { TIB }^{*} & .917,1.1 & - & 0 & 2500 & 150 \\ \text { 1b } & 12,000 & .46 & \mathrm{NaOH} & 200 & 2400 & 3 \\ 1 \mathrm{c} & 12,000 & .42 & - & 0 & 2500 & 5 \\ \text { ld } & 10,000 & .1 & - & 0 & 2500 & 1\end{array}$

Test 2 used a standard matrix (B) and has two 3 in. sections coated

$\begin{array}{rcccrrrrr}2 \mathrm{a} & 12,000 & .46 & \mathrm{NaOH} & 200 & 2500 & 2 & & \\ 2 \mathrm{~b} & 12000 & .46 & - & 0 & 2500 & .1 & \mathrm{~L}=86 & 9 \\ & & & & & & & & \\ 3 \mathrm{a} & 12,000 & 1.0 & \mathrm{NaOH} & 200 & 2500 & 11 & 23 & 16 \\ 3 \mathrm{~b} & 12,000 & 1.0 & \mathrm{NaOH} & 200 & 2500 & 3 & 29 & 16 \\ 3 \mathrm{c} & 12,000 & 1.0 & \mathrm{NaOH} & 200 & 2500 & 3 & 40 & 16 \\ 3 \mathrm{~d} & 12000 & 1 . & \mathrm{NaOH} & 200 & 2500 & 11 & 47 & 16\end{array}$

Test 4 used a standard matrix (B) with 56 cracks. . .

$\begin{array}{rcccrrrrr}4 & - & - & - & 0 & 100 & .1 & 14 & 16 \\ 4 \mathrm{a} & 12,000 & .917 & - & 0 & 2450 & .1 & 22 & 16 \\ 4 \mathrm{~b} & 13,000 & .5 & \mathrm{NaOH} & 200 & 2500 & 3 & 44 & 16 \\ 4 \mathrm{c} & 13,000 & .55 & - & 0 & 2500 & 5 & 37 & 16 \\ 4 \mathrm{~d} & 13,000 & .5 & \mathrm{NaOH} & 200 & 2500 & 6 & 54 & 16\end{array}$

Test 5 used a standard matrix (A)

$\begin{array}{ccccrcccc}5 & - & - & - & 0 & 100 & .1 & 6 & 16 \\ 5 \mathrm{a} & 11,500 & .917 & - & 0 & 2450 & .1 & 24 & 16 \\ 5 \mathrm{~b} & 13,700 & 1.1 & \mathrm{NaOH} & 200 & 2450 & 2 & 32 & 16 \\ 5 \mathrm{c} & 8,400 & 1.1 & - & 0 & 2450 & 6 & 34 & 15.5 \\ 5 \mathrm{~d} & 11,000 & 1.1 & \mathrm{NaOH} & 200 & 2450 & 3 & 36 & 16 \\ 5 \mathrm{e} & 11,000 & 1.1 & \mathrm{NaOH} & 200 & 2450 & 3 & 36 & 16 \\ 5 \mathrm{f} & 7,700 & .917 & \mathrm{NaOH} & 200 & 2350 & 3 & 44 & 16.2 \\ 5 \mathrm{~g} & 7,700 & .917 & \mathrm{NaOH} & 200 & 2350 & 5 & 52 & 16.4\end{array}$

Test 6 used a segretated matrix in the third pass (B)

$\begin{array}{lllllllll}6 \mathrm{a} & 11,000 & .917 & - & 0 & 2450 & .1 & 21 & 12 \\ 6 \mathrm{~b} & 12,000 & 1.1 & \mathrm{NaOH} & 200 & 2450 & 3 & 2 & 16 \\ 6 \mathrm{c} & 12,000 & .5 & \mathrm{NaOH} & 200 & 2450 & 5 & 35 & 16\end{array}$

Test 7 used a "solid edge" matrix (B)

$\begin{array}{llllrrrrr}7 \mathrm{a} & 11,000 & .917 & - & 0 & 2450 & .1 & 10 & 16 \\ 7 \mathrm{~b} & 13,000 & .5 & \mathrm{NaOH} & 200 & 2450 & 2 & 21 & 16 \\ 7 \mathrm{c} & 13,000 & .5 & \mathrm{NaOH} & 200 & 2450 & 6 & 26 & 16 \\ 7 \mathrm{~d} & 13,000 & .5 & \mathrm{NaOH} & 200 & 2450 & 5 & 73 & 16\end{array}$

* Technical Information Bulletin (various flows, flow ratios, and temperatures) 
TABLE 5 (cont'd)

Corrosion tests on GTE R1500 TPX Cramic Matrix

Test $Q(e)$ Flow Ratio Corrosive Corrosive Temp. Time Leakage Pressure \begin{tabular}{llllllll}
$\#$ & SCFHQ(a) / Q(e) & Type & g & ${ }^{\circ}$ & H & $\% Q(a)$ & osi \\
\hline
\end{tabular}

Test 8 used a standard matrix (B) coated with Zirmul (dipped)

$\begin{array}{lllllllll}8 \mathrm{a} & 11,000 & .917 & - & 0 & 2450 & .1 & 27 & 16 \\ 8 \mathrm{~b} & 11,000 & .5 & \mathrm{NaOH} & 200 & 2450 & 2 & 33 & 16 \\ 8 \mathrm{c} & 11,000 & .5 & \mathrm{NaOH} & 200 & 2450 & 5 & 49 & 16 \\ 8 \mathrm{~d} & 11,000 & .5 & \mathrm{NaOH} & 200 & 2450 & 5 & 71 & 16\end{array}$

Test 9 used a standard matrix (B) coated with Zirmul (dipped,baked on)

$\begin{array}{ccccccccc}\text { g } & - & - & - & 0 & 100 & .1 & 4 & 16 \\ 9 \mathrm{a} & 12,000 & .917 & - & 0 & 2450 & .1 & 14 & 16 \\ 9 \mathrm{~b} & 13,000 & .5 & \mathrm{NaOH} & 200 & 2450 & 2 & 13 & 16 \\ 9 \mathrm{c} & 12,000 & .5 & \mathrm{NaOH} & 200 & 2450 & 5 & 13 & 16 \\ 9 \mathrm{~d} & 12,000 & .5 & \mathrm{NaOH} & 200 & 2450 & 5 & 11 & 16 \\ 9 \mathrm{e} & 12,000 & .5 & \mathrm{NaOH} & 200 & 2450 & 5 & 18 & 16 \\ 9 \mathrm{e} & 12,000 & .5 & \mathrm{NaOH} & 200 & 2450 & 5 & 12 & 16 \\ 9 \mathrm{f} & 12,000 & .5 & - & 0 & 100 & .1 & 21 & 16\end{array}$

Test 10 used a standard matrix (B) coated with Zirmul (dipped,baked on) 10

$\begin{array}{lll}10 \mathrm{a} & 12,000 & .917\end{array}$

$\begin{array}{lll}10 \mathrm{~b} & 12,000 & .5\end{array}$

$10 \mathrm{c} \quad 12,000 \quad .5$

$\begin{array}{lll}10 \mathrm{~d} & 12,000 & .5\end{array}$

$10 \mathrm{e} \quad 12,000 \quad .5$

$10 \mathrm{e} \quad 12,000 \quad .5$

$\begin{array}{crcc}- & 0 & 100 & \\ \mathrm{NaOH} & 300 & 2450 & 2450 \\ \mathrm{NaOH} & 200 & 2450 & 5 \\ \mathrm{NaOH} & 200 & 2450 & 5 \\ \mathrm{NaOH} & 200 & 2450 & 5 \\ - & 0 & 100\end{array}$

.1

$4 \quad 16$

$18 \quad 16$

$14 \quad 16$

$28 \quad 16$

$39 \quad 16$

$45 \quad 16$

Test 11 used a standard matrix (B)

\section{1}

$\begin{array}{lll}11 \mathrm{a} & 12,000 & .917\end{array}$

$11 \mathrm{~b} \quad 15,000 \quad .4$

11c $15,000 \quad .4$

$\begin{array}{lll}11 \mathrm{~d} & 15,000 \quad .4\end{array}$

$11 \mathrm{e} \quad 15,000 \quad .4$

11f $\quad 15,000 \quad .4$

$11 \mathrm{~g} \quad 15,000 \quad .4$

$\mathrm{NaOH}$
$\mathrm{NaOH}$
$\mathrm{NaOH}$
$\mathrm{NaOH}$
$\mathrm{NaOH}$

Test 12 used a standard matrix (B)

$\begin{array}{crcc}- & 0 & 100 & .1 \\ - & 0 & 2450 & .1 \\ \mathrm{NaOH} & 200 & 2450 & 2 \\ \mathrm{NaOH} & 200 & 2450 & 5 \\ - & 0 & 100 & 5\end{array}$

$\begin{array}{lll}100 & .1 & 5\end{array}$

$\begin{array}{rcc}0 & 100 & \\ 0 & 2450 & \\ 200 & 2450 & 3 \\ 200 & 2450 & 5 \\ 200 & 2450 & 5 \\ 200 & 2450 & 5 \\ 200 & 2450 & 5\end{array}$

16 6 16 16 16 6 6 16 6
6
6
6
6
6
16 $54 \quad 16$ 
TABLE 5 (cont'd)

Corrosion tests on GTE R1500 TPX Cramic Matrix

Test $Q$ (e) Flow Ratio Corrosive Corrosive Temp. Time Leakage Pressure \# SCFHQ(a)/Q(e) Type
Test 13 used a standard matrix (B)

$\begin{array}{rrrrrrrrr}13 & - & . & - & 0 & 100 & .1 & 3 & 16 \\ 13 \mathrm{a} & 12,000 & .917 & - & 0 & 2450 & .1 & 9 & 16 \\ 13 \mathrm{~b} & 12,000 & .5 & \mathrm{NaOH} & 200 & 2450 & 2 & 24 & 16 \\ 13 \mathrm{c} & 12,000 & .5 & \mathrm{NaOH} & 200 & 2450 & 5 & 33 & 16 \\ 13 \mathrm{~d} & 12,000 & .5 & \mathrm{NaOH} & 20 \mathrm{C} & 2450 & 5 & 91 & 16 \\ 13 \mathrm{e} & 12,000 & .5 & - & 0 & 1005 & .1 & 100 & 16\end{array}$

Test 14 used a "solid edge" matrix (B), with Zirmul (baked on), cube delaminated $\begin{array}{ccccccccc}14 & - & - & - & 0 & 100 & .1 & 6 & 16 \\ 14 \mathrm{a} & 11,000 & .917 & - & 0 & 2450 & .1 & 100 & 16\end{array}$

Test 15 used a MAS-8400 matrix with Zirmul Glue (B), extreme ambient leakage

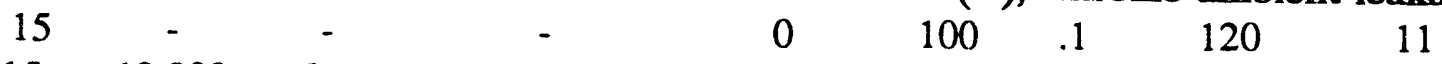

$\begin{array}{lllllllll}15 \mathrm{a} & 12,000 & .917 & - & 0 & 2450 & .1 & 24 & 16\end{array}$

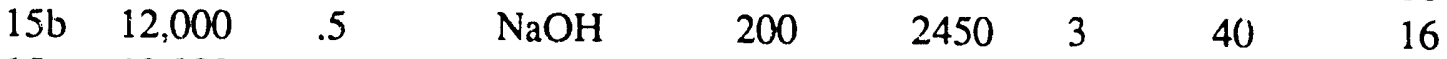

$\begin{array}{lllllllll}15 \mathrm{c} & 12,000 & .5 & \mathrm{NaOH} & 200 & 2450 & 2.5 & 56 & 16\end{array}$

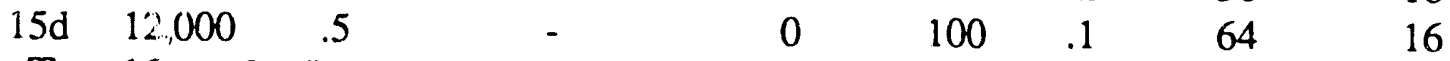

Test 16 used a "sciid edge" matrix (B), coited with Zirmul (dipped, baked on)

$\begin{array}{ccccccccc}16 & - & - & - & 0 & 100 & .1 & 4 & 16 \\ 16 \mathrm{a} & 11,000 & .917 & - & 0 & 2450 & .1 & 6 & 16 \\ 16 \mathrm{~b} & 11,000 & .5 & \mathrm{NaOH} & 200 & 2450 & 2 & 7 & 16 \\ 16 \mathrm{c} & 11,000 & .5 & \mathrm{NaOH} & 200 & 2450 & 5 & 11 & 16 \\ 16 \mathrm{~d} & 11,000 & .5 & \mathrm{NaOH} & 200 & 2450 & 5 & 14 & 16 \\ 16 \mathrm{e} & 11,000 & .5 & \mathrm{NaOH} & 200 & 2450 & 5 & 17 & 16 \\ 16 \mathrm{f} & 11,000 & .5 & \mathrm{NaOH} & 200 & 2450 & 5 & 22 & 16 \\ 16 \mathrm{~g} & 11,000 & .5 & - & 0 & 100 & .1 & 25 & 16 \\ \text { Test } & 17 \text { used a standard matrix (B) } & & & & & \\ 17 & - & - & - & 0 & 100 & 3 & 15 & 16 \\ 17 \mathrm{a} & 12,000 & .917 & - & 0 & 2450 & .1 & 40.7 & 16 \\ 17 \mathrm{~b} & 12,000 & .5 & \mathrm{NaOH} & 200 & 2450 & 3 & 42 & 16 \\ 17 \mathrm{c} & 12,000 & .5 & \mathrm{NaOH} & 200 & 2450 & 5 & 82 & 14 \\ 17 \mathrm{~d} & 12,000 & .5 & - & 0 & 100 & .1 & 100 & 16\end{array}$


To allow for expeditious review and evaluation of potential materials and corrosion resistant coatings a corrosion test facility was fabricated. The test bed would evaluate cross flow matrix shapes in sizes of $3 \times 3 \times 3$ in. Coatings could be applied to the existing cordieritemixed -oxide ceramic (MAS-8400) or a matrix of alternate materials could be evaluated. The furnace would expose both a sample and one or two controls (standard MAS-8400 ceramic matrix elements). Comparisons would be based upon qualitative results (degree of melting or softening). If possible quantitative comparisons would be made by measuring the amount of change in thermal expansion coefficient of the matrix substrate. If corrosive attack creates a glassy phase a dramatic increase in the thermal expansion of the material would be observed.

A GTE funded test program to evaluate coatings (commercially available and ones developed by GTE such as $\mathrm{Al}_{2} \mathrm{O}_{3}$ ) was established. The contract effort did not call for the fabrication of full matrix elements of Z-1000 or testing Z-1000 coatings via this test method, however GTE was able to run these inexpensive experiments concurrently with the process development tasks described in section 3 of this report. The technique offered the potential for early determination of the merit of the zirconia-mullite based ceramic (Z-1000).

The corrosion test stand has the following specifications:

- Chamber size (internal) $8 \times 8 \times 24$ (in.)

- K-3000 refractory brick with tie rod support

- Two 35,000 Btu/h nozzle mix burners fire from opposite ends (24 in.)

- Automatic purge, ignition, temperature control and flame safety

- Three exhaust flues $(2 \times 2$ in.) spaced evenly along the units length

- Thermocouples (type $S$ ) at each flue

- On ratio or excess air temperature controi

The furnace utilizes a $3 \times 3 \times 3$ in. (test matrix), located on each flue. A small alumina crucible is located directly under each flue, and sits on a refractory platform. A refractory baffle hangs down from the refractory roof $4 \mathrm{in}$. Its function is to help direct the contaminant (generally $\mathrm{NaOH}$ ) directly into the exhaust flue above the crucible. The burners are located on opposite side of the walls but are offset from one another as illustrated in the flow diagram depicted in Figure 7 and the cross-section schematic shown in Figure 8. The flames do not directly impinge in the crucibles, which are centrally located below each flue during a test. The burners are located approximately 4.5 in. above the refractory hearth.

A series of tests was run with MAS-8400 matrix elements (control) on each flue. Unlike the matrix shown in Figure 5, these elements do not have combustion air flow passing through them during the test. The "dead zone" of a recuperator has no air flow, however it is cooler than 


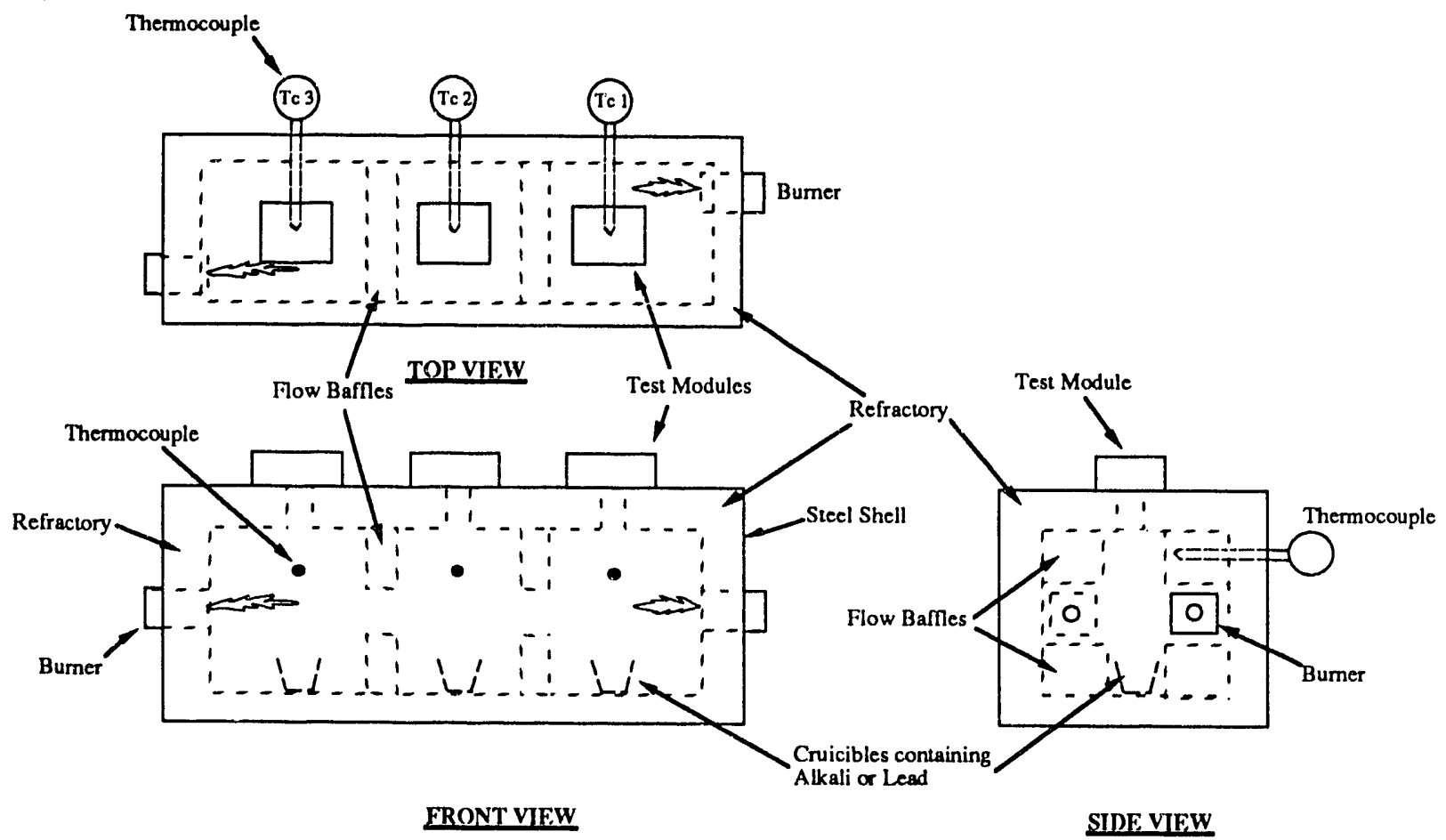

Figure 7

\section{Corrosion Test Stand}

the exhaust inlet due to the heat transferred to the section that participates in heat exchange. The net result is that the test performed on the test stand will actually be more severe. The corrosion rate may increase resulting in the need for a lower temperature, shorter exposure duration or both. The use of controls eliminates the need to fully duplicate what occurs on a full scale test. It was determined that a $10 \mathrm{~g}$ sample of $\mathrm{NaOH}$ run at $2450^{\circ} \mathrm{F}$ for $6 \mathrm{~h}$ produced a surface similar to that shown in Figure 5. Additionally, the thermal expansion of the "glassy" material showed a $350 \%$ increase in expansion in the room-temperature to $600^{\circ} \mathrm{F}$ range which compares to historical data obtained from "post mortem analysis" (technique is detailed in reference 3) of recuperators returned for rebuild and refurbishing. Figure 9 shows the exhaust inlet of the exposed test elements. The rounding of the corners, and melting of the ribs is evident.

A test with the central flue plugged off was run to determine the consistency of the corrosion comparison test. Furnace adjustments were made to insure balanced input, exhaust flow, and temperature. Figure 10 illustrates the consistency between the corrosion experienced by the matrix elements placed on each of the two flues. The test was repeated several times to insure consistency. 


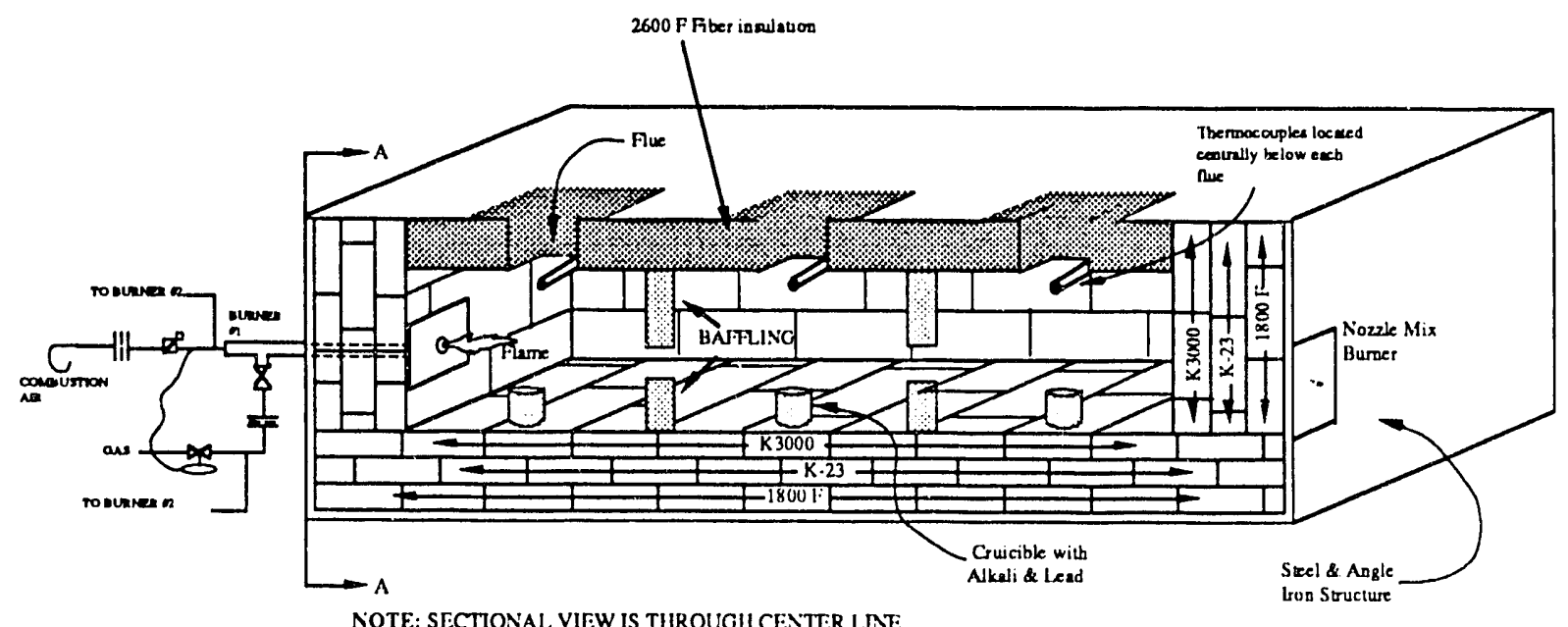

NOTE: SECTIONAL VIEW IS THROUGH CENTER LNE OF CORROSION TEST FURNACE

Figure 8

Schematic of the Corrosion Test Stand

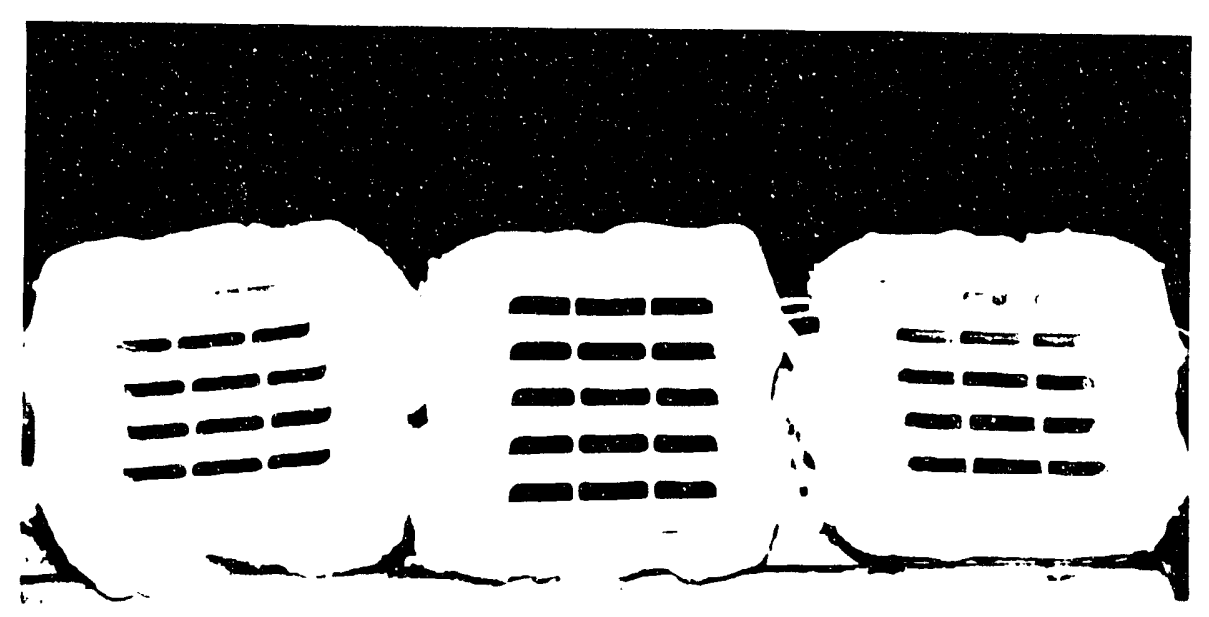

Figure 9

MAS - 8400 (Cordierite-Mixed-Oxide) Test Modules

after Exposure to $10 \mathrm{~g}$ (each) $\mathrm{NaOH}$ at $2450 \cdot \mathrm{F}$ for $6 \mathrm{~h}$ 


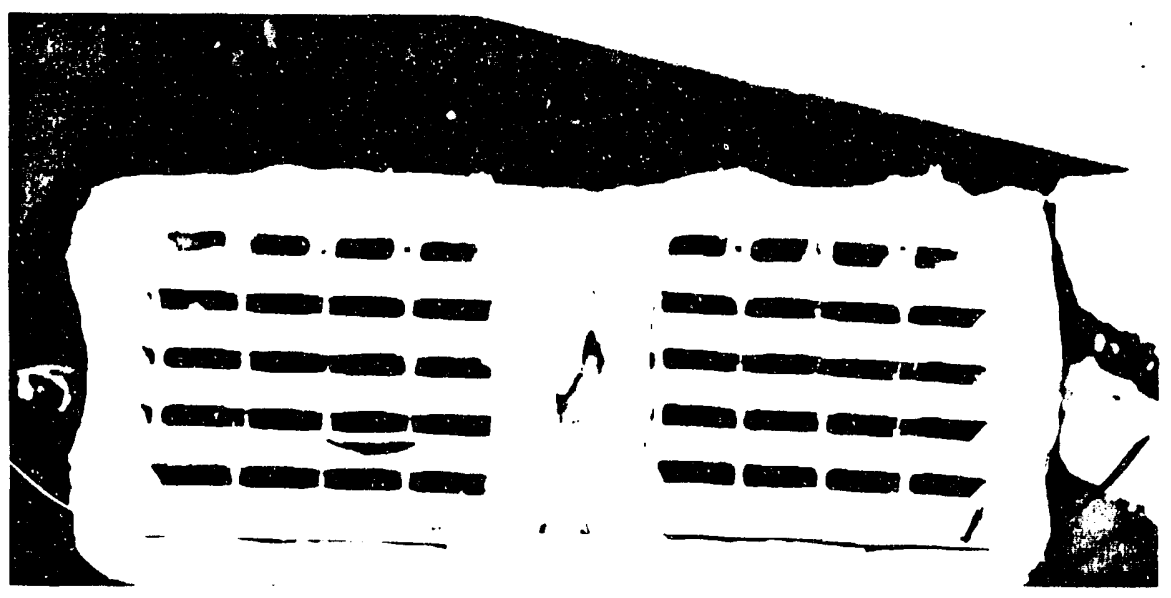

Figure 10

MAS - 8400 (Cordierite-Mixed-Oxide) Test Modules after Exposure to $10 \mathrm{~g}$ (each) $\mathrm{NaOH}$ at $2450^{\circ} \mathrm{F}$ for $6 \mathrm{~h}$

A series of compositions were prepared with various mixtures of zirconia-nullite based material (Zirmul") and a Staywhite Talc (required to "flux" the Zirmul). The following procedure was used:

- The compositions were all milled for 40 h in a Sweco DM-10) (urethane) vibratory mill. The media utilized was $1 / 2$ in. capped cylinders of alumina (Coors $99.5 \%$ $\mathrm{Al}_{2} \mathrm{O}_{3}$ ). The mill was set to $30^{\circ}$ angle and utilized 2 top plates and 3 bottom plates. A media:load charge ratio (by weight) of approximately 18:1 was utilized. Contamination $\left(\mathrm{Al}_{2} \mathrm{O}_{3}\right.$ addition) to the $\mathrm{Z}-1000$ was measured at approximately $1.3 \%$ (by weight).

- Additions of 5,10,15, and 20\% talc* were made subsecquent to the milling. Each sample was then milled for $8 \mathrm{~h}$ on a Sweco (model \# DM $18 / 5$ ) mill in 1 gallon (urethane lined) stainless steel containers. A charge ratio of 10:1 was utilized, and the media was identical to that utilized in the DM-10 mill.

- After milling the compositions were pelletized in a jar mill with the addition of approximately 5 weight percent water.

- The pellets were then fired to 2650, 2700) and 2750\% F on alumina trays.

- The sintered agglomerates were then wet milled for 8 hours in 1 gallon vibratory mills with 2500 cc deionized water

- The slurry was then screened through a 100 mesh screen.

* Taylor Refractorics Grade 361 and 362

$+\quad$ Cyprus Industrial Mincrals Co, Talc Division 
- The sample was heated to $140^{\circ} \mathrm{F}$ until dry.

- A 20\% (volume) suspension in deionized- $\mathrm{H}_{2} \mathrm{O}$ was prepared.

- Polyvinyl-alcohol (PVOH) was added (1\% by weight of solids).

- The suspensions were dip coated onto $3 \times 3 \times 3$ in. MAS-8400 ceramic test elements that were dried at $140^{\circ} \mathrm{F}$ prior to dipping. The slurry was thinned and dip time was adjusted to foster a coating less than $.010 \mathrm{in}$. thick. The matrix were air dried while suspended on the wire used for dipping.

- The Zirmul based coated matrix elements were all fired to $2500^{\circ} \mathrm{F}$ in air to foster a bond and assure that the material would not spall off the matrix during the test (at $2450^{\circ} \mathrm{F}$ ). The ramp was $100^{\circ} \mathrm{F} / \mathrm{h}$ with a $2 \mathrm{~h}$ hold at temperature. Several attempts were often made to bond the coating to the matrix, as the mismatch in thermal expansion between the MAS- 8400 and the Zirmul based coatings often caused the coating to spall off. As a rule, the thinner the coating, the better the adherence.

This application technique was similar to one developed for testing other corrosion resistant coatings. CVD $\mathrm{SiC}$, alumina precipitated on the matrix via an alkoxide process and the other coatings (detailed in Table 5) were evaluated by GTE during the aforementioned internally funded project. None of the materials performed as well as the Zirmul based materials.

Figure 11 shows the result of a side-by-side comparison test on the corrosion test stand. The standard test $\left(10 \mathrm{~g} \mathrm{NaOH} @ 2450^{\circ} \mathrm{F}\right.$ for $6 \mathrm{~h}$ ) was run and repeated two times with this material. Vaporization rates for the $\mathrm{NaOH}$ were not determined, however the degree of melting (on an uncoated matrix) did continue to increase throughout the duration of the test. Additional tests were done with lead oxide. These tests were done prior to a refractory rebuild. The results were similar to those with the $\mathrm{NaOH}$ (Figure 12). X-ray diffraction patierns of the material found on the exposed face of matrix samples of full-scale and sub-scale tests showed the presence of a typical MAS-8400 cordierite pattern and PDF19-1227. This pattern is either $\left(\mathrm{Na}\right.$ or $\mathrm{K}$ ) $-\mathrm{Al}-\mathrm{Si}_{13} \mathrm{O}_{8}$ or $\mathrm{Pb}-\mathrm{Al}_{2} \mathrm{Si}_{12} \mathrm{O}_{8}$. Review of appropriate phase equilibria data suggest that low temperature eutectics would be formed, and melting and/or softening of the ceramic is predictable.

Full-scale test \# 16, (detailed in Table 5), illustrated the potential of Zirmul to extend life cycles. During sub-scale tests the positions of the control matrix (uncoated) and the test matrix (coated) reversed. A significant reduction in the degree of softening of the MAS matrix substrate (similar to that observed in full scale tests) was observed. The material used in this test was Zimul-361 with $15 \%$ talc addition, which was milled and presintered at $2700^{\circ} \mathrm{F}$. This 
material seemed to adhere to the MAS- 8400 substrate better than other coatings. The softening of the leading edges, and the formation of a glassy phase evident in the control sample was not observed in the coated test matrix. A sample of MAS- 8400 sample was extracted from the leading face of the coated matrix.

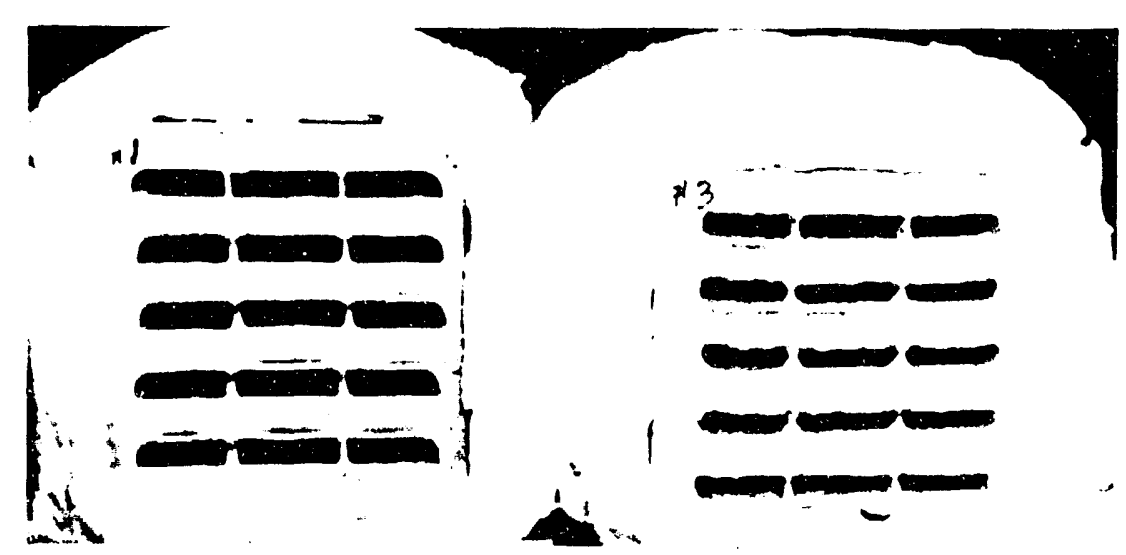

Figure 11

Uncoated MAS - 8400 (Cordierite-Mixed-Oxide) Test Module (Left) and MAS-8400 module coated with Zirmul-361 with $15 \%$ Talc $\left(2777^{\circ} \mathrm{F}\right)$ after exposure to $10 \mathrm{~g}$ (each) $\mathrm{NaOH}$ at $2450^{\circ} \mathrm{F}$ for $6 \mathrm{~h}$

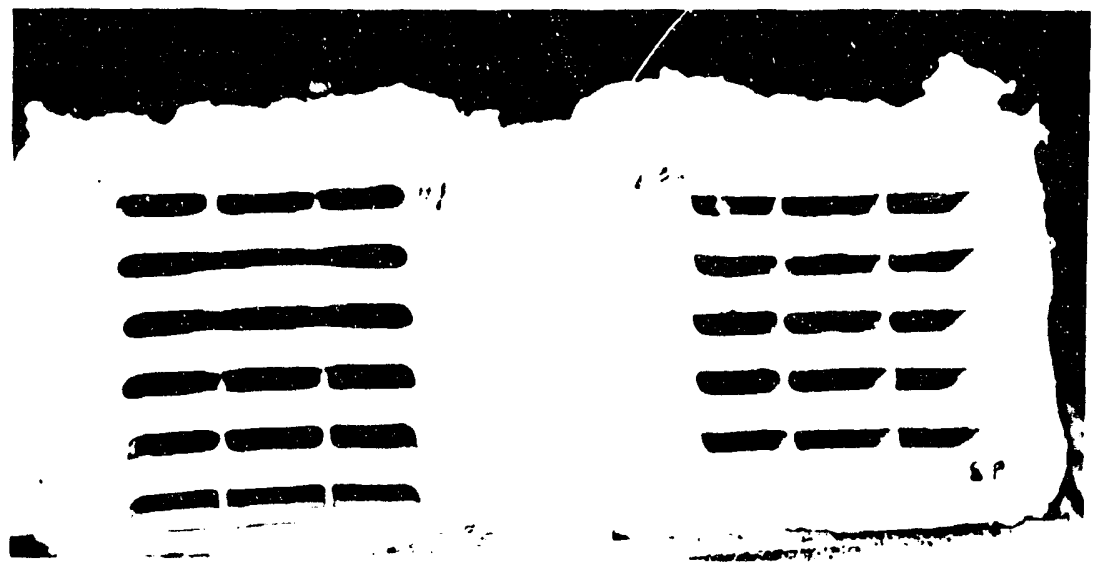

Figure 12

Uncoated MAS - 8400 (Cordierite-Mixed-Oxide) Test Module (Left) and MAS-8400 module coated with Zirmul-361 with $15 \%$ Talc $\left(2777^{\circ} \mathrm{F}\right)$ after exposure to $10 \mathrm{~g}$ (each) $\mathrm{PbO}$ at $2450^{\circ} \mathrm{F}$ for $6 \mathrm{~h}$ 
Optical micrographs (Figure 13) contrast the coated and uncoated substrate after the exposure test. The coating was ground off and the coefficient of linear thermal expansion of the cordierite (RT $-800^{\circ} \mathrm{F}$ ) was measured at approximately $2.1 \times 10^{-6} /{ }^{\circ} \mathrm{F}$. This is similar to that measured for MAS- 8400 prior to exposure to corrosive materials. This is dramatically lower than those measured in the glassy area (tests up to $500^{\circ} \mathrm{F}$ were done and expansion rates up to $6.0 \times 10-6{ }^{\circ} \mathrm{F}$ have been measured, when samples were corrosion-tested). The positive results obtained here focused the development effort for the Zirmul based materials on the Z-361 with $15 \%$ additions, sintered at $2777^{\circ} \mathrm{F}$.

Figure 13 Not Available 


\subsection{Z-1000 Extrusion Process Development}

\subsubsection{Summary of the MAS-8400 Manufacturing Process}

The process used to manufacture the MAS- 8400 cordierite ceramic crossflow recuperator matrix was used as a model for extrusion process development, fabrication, green machining, binder removal/ sintering / annealing and inspection procedures envisioned for the zirconia - mullite mixed-oxide composition. The MAS- 8400 matrix is manufactured via the following procedure:

1. The following materials are added to an Eirich Mixer Model (dust collector on):

- Inorganic Additives:

- Alumina (after hammer-milling)

- Staywhite Talc

- Pyrax B

- $\quad$ M-23 Ball Clay (<2\% for extrudability enhancement)

- Organic Additives (Dry):

- Polyethylene-glycol (PEG)

- Hydro-ethyl-cellulose (HEC)

2. Mix for 10 minutes, counter-rotating drum, impeller at low speed.

3. Add the following solution to the blended powders (wet mix):

- Tri-ethylene-glycol (TEG)

- de-ionized $\mathrm{H}_{2} \mathrm{O}$

- $\quad$ Polyethylene-glycol (PEG)

4. Mix for 10 minutes, counter rotating drum, impeller at high speed.

5. Mix until material balls up into 1-2 in. spheres at low speed, co-rotation (approximately 15 minutes). Temperature should not exceed $135^{\circ} \mathrm{F}$.

6. Discharge mixture into doubled plastic bags, seal and store at room temperature.

7. Charge 200T, 8 in. extruder with $30 \mathrm{~kg}$ (approximately) compounded mixture.

8. Close ram and compress mixture into die holder assembly, until material begins to extrude through the 200 die (Fig 14).

9. Open ram and fill extrusion barrel completely (approximately $30 \mathrm{~kg}$ ).

10. Close ram to minimal compression of the mix, but enough to assure that the vacuum ring seal is inside the barrel.

11. Turn on vacuum pump, verify that a vacuum seal exists at the die end of the barrel (indicated by negative gauge pressure) and run 10 minutes.

12. Extend ram until compounded material begins to flow, withdraw ram, fill barrel with compounded material and repeat vacuum cycle (approximately $20 \mathrm{~kg}$ ). 


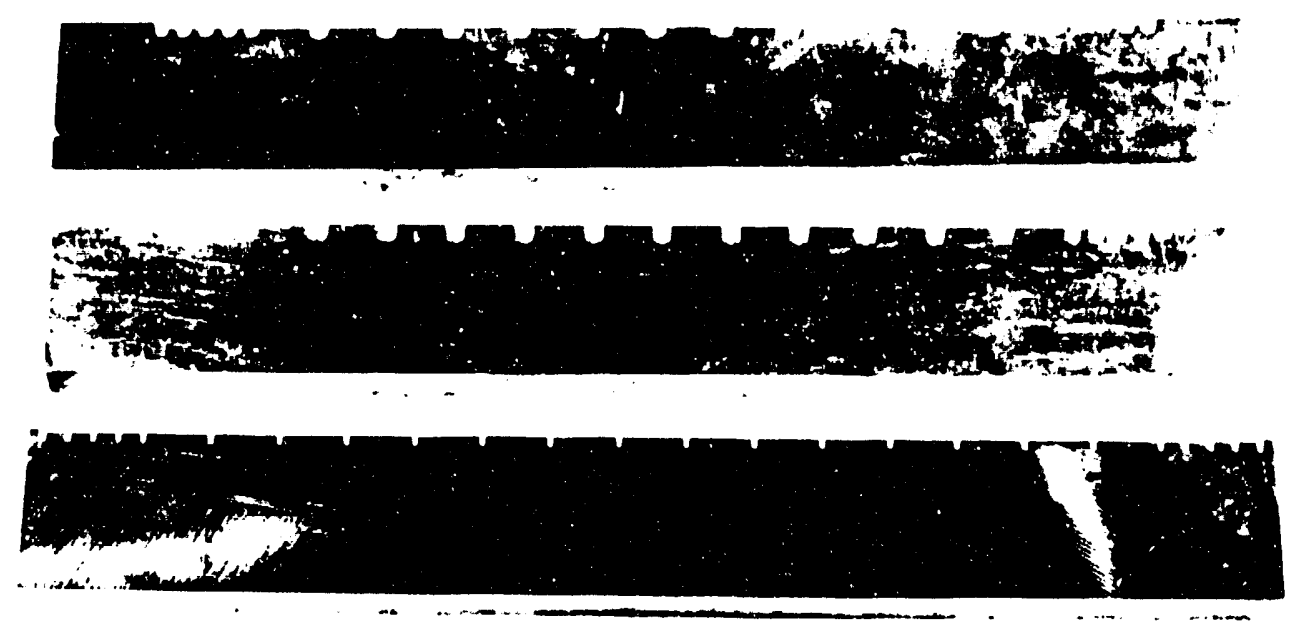

\section{Figure 14}

\section{Extrusion dies for Extrusion of plate/fin sheets of Ceramic}

13. Adjusi extrusion pressure to 60T (bypass valve), and set extrusion die flowrestriction adjustment screws to foster uniform flow of the sheet. Objective is flatness, uniform thickness and tear-free sheets running continuously.

14. Monitor extrusion wall thickness to insure that the differential thickness between the center of the sheet and the outside edges is less than .002 in. If it exceeds this replace the worn die insert.

15. Extrude sheets to 38 or 44 in. lengths (for $10 \times 10$ or $12 \times 12$ in. widths, respectively) onto $24 \times 48 \times 0.5$ in. trays. (trays are plastic light diffusers with .020 in.wall thickness and $.375 \times .375$ in.holes) ${ }^{*}$.

16. Cut sheets to length (10 or 12 in.).

17. Place into air dryer for 45 minutes (trays are stacked 2 in. apart in a box with ambient air circulating above and below each tray)

18. Dry in high volume replacement air oven (Dispatch) at $140^{\circ} \mathrm{F}$ for $2 \mathrm{~h}$

19. Remove from oven and stack sheets in 12 in. heights. The base sheet is comprised of a sheet with the rips facing up with a second sheet placed over it with its ribs parallel to the base sheet's ribs (interlocked), facing down (Figure 15). Sheets are then stacked with ribs facing down, in an alternating manner that fosters a crossflow shape.

- The actual die sizes are made oversized to accommodate shrinkage. Shect widths and lengths are 11.0 in. For the $10 \times 10 \times 10 \mathrm{in}$. unit and $13.0 \mathrm{in}$. for the $12 \times 12 \times 12$ in recupcrator. 


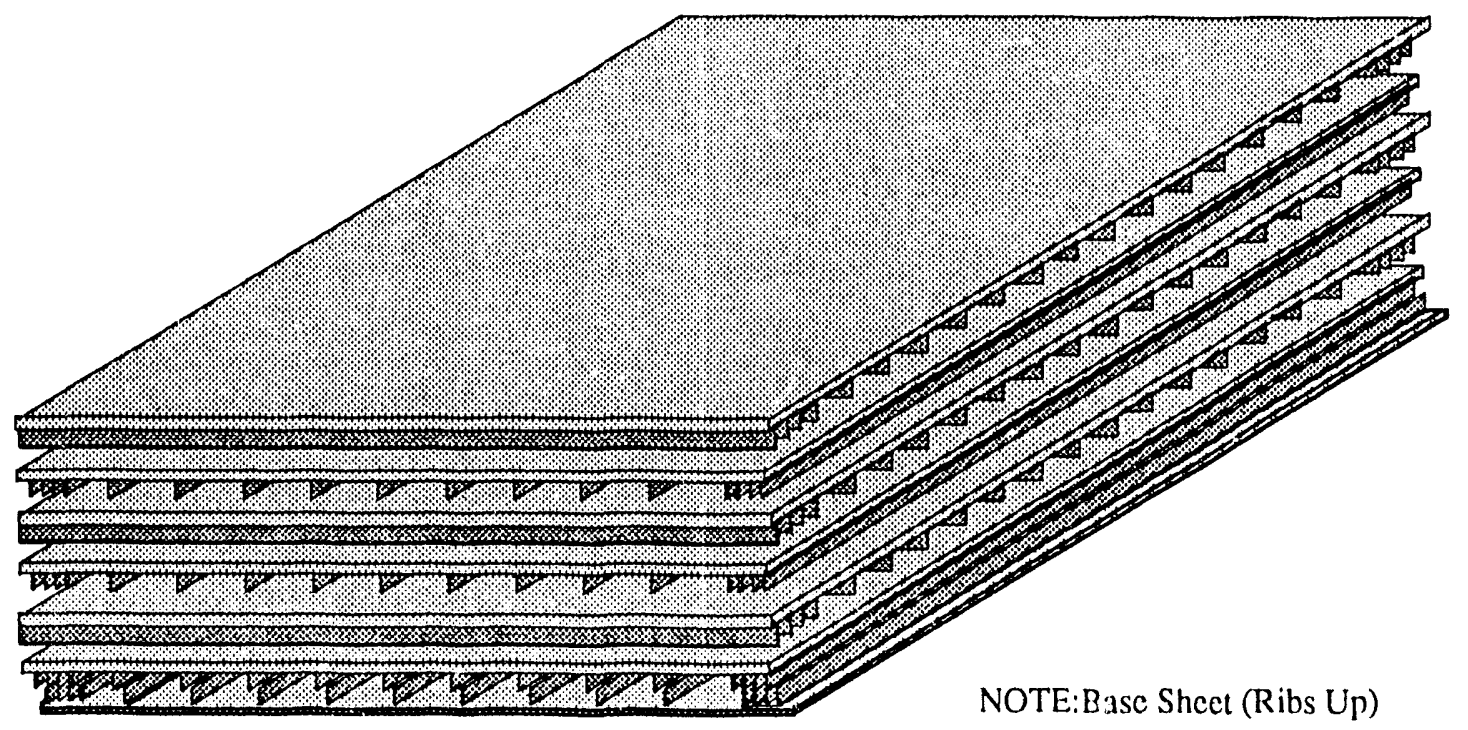

Figure 15

\section{Assembly Illustration for GTE Ceramic Crossflow Recuperator}

20. Place $11 \times 11 \times .5$ or $13 \times 13 \times .5$ in. steel plates on the stack (for $10 \times 10$ or $12 \times$ 12 in. sheet extrusions, respectively).

21. Units are constructed in a jig that ensures that alternate layers are normal $\left(90^{\circ}\right)$ to one another. Sheets are inspected for flatness, and only sheets that are cut square are used.

22. Each sheet is positioned then coated with a deflocculated MAS- 8400 slurry (Darvan $\mathrm{C}$ in a 40 volume percent aqueous (deionized $\mathrm{H}_{2} \mathrm{O}$ ) suspension containing PEG and HEC). The slurry is rolled on with a thin nap roller. Another sheet is then placed on it (at $90^{\circ}$ ) immediately. Process is repeated for 10 sheets, and then weight is applied using steel plates for 10 minutes. Process is continued until the appropriate height is obtained $(10.2,12.3$ or 18.5 in. for models R0600, R 1000 or R1500, respectively).

23. The units are then cut to the proper widths. A 0.5 in. cut is made in each of the walls that contacted the building jig. The other walls are trimmed to create $9.9 \times 9.9 \mathrm{in}$. or $11.9 \times 11.9$ in. thickness (for $10 \times 10$ or $12 \times 12$ in. units, respectively).

24. Units are placed on a set of interlocked MAS-8400 ceramic sheets with an alumina sand layer and positioned in the Bickley High Temperature Furnace. An alumina sand layer is placed on the top of the recuperator matrix, and MAS-8400 ceramic sheets are placed on top. Units are stacked up to $48 \mathrm{in.} \mathrm{high,} 3$ abreast. The unit on top has an 1 in. thick alumina setter that covers the entire matrix. Care is taken to ensure that the units are positioned on level flat surfaces. 
25. The Bickley Bell Kiln is lowered, and then the hearth rotation apparatus, environmental protection devices and power supply are turned on. The four zone control system is pre-programed to carry out a proprietary one step binder-burnout/ sintering/anneal thermal cycle. The entire cycle takes place under an air atmosphere, however, the binder removal cycle requires that the furnace be starved of oxygen during the exothermic portions of the binder burnout cycle (oxygen is consumed by the oxidized organics). Ramp rates were selected to minimize the differential temperature across a matrix element to $<18 \mathrm{~F}^{\circ}$ (the center actually gets hotter than the outside of the matrix). Sintering temperatures require an extended hold at $2525^{\circ} \mathrm{F}$. A controlled cool to an annealing temperature fosters crystallization of any glass formed at the high soak temperature. Final cooling rates are limited to the ability of the furnaces dense alumina refractory to dissipate its stored heat (approximately $24 \mathrm{~h}$ ). Up to 36 cubic feet ( 800 pounds) of ceramic heat exchanger matrix elements can be sintered simultaneously. Automatic controls determine the time temperature profile, ensure zone-to-zone thermal uniformity $\left(+/-8^{\circ} \mathrm{F}\right)$ control damper positions, exhaust gas flow, and environmental systems. Status is remotely monitored and recorded on local and remote strip chart recorders.

26. Units are unloaded, inspected for cracks (no visible cracks are accepted), pressure tested to determine structural integrity (to 5-8 psi) and leak tested (must be less than $10 \%$ of it nominal rating during operation). Leakage rates are generally in the $<1 \%$ range.

\subsubsection{Milling Studies}

The particle size distribution (PSD via Micrometrics sedigraph), surface area (SA via Quantachrome Monosorb BET), and density (via Quantachrome Null-pycnometer) determined for Zirmul 361, Staywhite talc and MAS-8400 mixture and are shown in Table 6. GTE has had prior experience relating to extrusion with the aforementioned binder system, and decided to attempt to match (approximate) the volume loading, mean particle size and surface area of the production MAS- 8400 material.

Milling experiments were undertaken because of the course nature of the Zirmul-361 powder. A Sweco mill (M18-5) was used for a 40h milling experiment. A sample was extracted every 8 hours, and surface areas (BET) and particle size distributions were determined (via sedigraph). Table 7 shows the results of the draw trials. The same test was repeated using a rolling mill and one gallon polypropylene bottles (Table 8 ). The charge ratio (media:charge) was $8: 1$ (by weight) and 0.25 in. diameter capped cylinders (Coors $99.5 \%$ 
Table 6

Properties of MAS-8400, Zirmul-361 and Staywhite Talc

$\begin{array}{lccc}\text { MATERIAL } & \text { DENSTTY (abs.) } & \text { SURFACE AREA } & \text { mean-PSD } \\ & \mathrm{g} / \mathrm{cm}^{3} & \mathrm{~m}^{2} / \mathrm{g} & \mu \mathrm{m} \\ \text { MAS-8400 } & 2.99 & 10.028 & 5.005 \\ \text { Zirmul-361 } & 3.77 & 0.588 & 12.400 \\ \text { Staywhite Talc } & 2.94 & 11.120 & \end{array}$

Table 7

Sweco Milling Effectiveness (model - M-18/5) of Zirmul-361, A Time Study, 1 Gallon Lined Containers with $4.0 \mathrm{Kg}$ of 0.25 in. capped $\mathrm{Al}_{2} \mathrm{O}_{3}$ Cylinders. The media:charge ratio was 8:1 (by weight).

$\begin{array}{ccccc}\begin{array}{c}\text { TIME } \\ \text { (hours) }\end{array} & \begin{array}{c}\text { SURFACE AREA } \\ \mathrm{m}^{2} / \mathrm{g}\end{array} & \begin{array}{c}\text { CALCULATED } \\ \text { DIAMETER }(\mu \mathrm{m})\end{array} & \begin{array}{c}\text { BULK DENSITY } \\ \mathrm{g} / \mathrm{cm}^{3}\end{array} & \begin{array}{c}\text { SEDIGRAPH (PSD) } \\ \text { Mean-Diameter }(\mu \mathrm{m})\end{array} \\ 0 & 0.44 & 3.56 & 1.034 & \mathrm{~N} / \mathrm{a} \\ 8 & 1.29 & 1.23 & 1.040 & 6.799 \\ 16 & 1.82 & 0.88 & 1.017 & 3.813 \\ 24 & 2.04 & 0.78 & 1.052 & 3.317 \\ 32 & 2.03 & 0.78 & 1.024 & 3.119 \\ 40 & 2.52 & 0.63 & 1.044 & 2.651\end{array}$

Table 8

Ball Milling Effectiveness of Zirmul-361, A Time Study, 1 Gallon Polypropylene Bottles with $4.0 \mathrm{Kg}$ of 0.25 in. capped $\mathrm{Al}_{2} \mathrm{O}_{3}$ Cylinders The media:charge ratio was 8:1 (by weight).

$\begin{array}{ccccc}\begin{array}{c}\text { TIME } \\ \text { (hours) }\end{array} & \begin{array}{c}\text { SURFACE AREA } \\ \mathrm{m}^{2} / \mathrm{g}\end{array} & \begin{array}{c}\text { CALCULATED } \\ \text { DIAMETER }(\mu \mathrm{m})\end{array} & \begin{array}{c}\text { BULK DENSITY } \\ \mathrm{g} / \mathrm{cm}^{3}\end{array} & \begin{array}{c}\text { SEDIGRAPH (PSD) } \\ \text { Mean-Diameter }(\mu \mathrm{m})\end{array} \\ 0 & 0.44 & 3.56 & 1.034 & \text { N/a } \\ 8 & 1.14 & 1.40 & 1.040 & 5.661 \\ 16 & 1.40 & 1.14 & 1.017 & 4.779 \\ 24 & 1.86 & 0.86 & 1.052 & 4.098 \\ 32 & 1.98 & 0.81 & 1.024 & 3.698 \\ 40 & 2.37 & 0.67 & 1.044 & 3.425\end{array}$


$\mathrm{Al}_{2} \mathrm{O}_{3}$ ) were used. The goai was to obtain a surface area in the range of $5-10 \mathrm{~m}^{2} / \mathrm{g}$. MAS- 8400 is compounded using raw material with a surface area of approximately $10.0 \mathrm{~m}^{2} / \mathrm{g}$. GTE has successfully compounded and extruded materials with surface areas as low as $5 \mathrm{~m}^{2} / \mathrm{g}$ using the binder system described earlier. MAS- 8400 contains $63.8 \%$ (weight) talc, which has a platy crystal structure which yields a large surface area:mass ratio. Extrusion of more spherical materials can be accomplished at a higher solids loading levels (less organic additives). Courser materials have a lower surface area:mass ratio than fine materials.

Sweco milling was the more effective attrition process and was selected for process upscale. The $40 \mathrm{~h}$ milling time (upper limit) selected for the experiments was based upon equipment availability and required department usage.

\subsubsection{Compounding and Extrusion Studies}

A Sweco DM-3 mill was loaded with $20.45 \mathrm{Kg}$ Zirmul-361 and clean 0.5 in. capped cylinders $\left(363.6 \mathrm{~kg}\right.$ of Coors $99.5 \% \mathrm{Al}_{2} \mathrm{O}_{3}$ ), and run for $21 \mathrm{~h}$ for the purpose of cleaning out the mill and checking the operation of the mill at full load. After cleaning, three batches of Zirmui361 were then milled according to the following procedure:

- Sweco DM-3 (urethane)

- $\quad$ angle $=30^{\circ}$

- 3 plates on bottom

- 2 plates on top

- $\quad 363.6 \mathrm{~kg}$ (Coors $99.5 \% \mathrm{Al}_{2} \mathrm{O}_{3}$ ) $0.5 \mathrm{in}$. capped cylinders

- $\quad 20.45 \mathrm{~kg}$ raw material (media charge:load = 18:1)

- Mill for $40 \mathrm{~h}$, discharge for $1 \mathrm{~h}$

The material was removed from the mill and the three batches were blended together (cone blender with an intensifier bar) for 30 minutes). This material was used for the six compounding experiments shown in Table 7. The properties of the milled Zirmul-361 blend were as follows:

- Surface Area (Zirmul-361)

$.5 .72 \mathrm{~m}^{2} / \mathrm{g}($ via BET)

- Average Particle Size Distribution ....2.667 $\mu \mathrm{m}$ (via sedigraph)

- Bulk Density. $0.955 \mathrm{~g} / \mathrm{cm}^{3}$

The compositions detailed in Table 9 were prepared for a compounding/extrusion trial. Additions of $0,5,10,15,20$, and $25 \%$ Staywhite talc were made to Zirmul-361. The solids loading of each batch was modified as indicated. The modifications were required to insure 
Table 9

\section{COMPOSITION OF COMPOUNDING TRIALS (Batch 1-6) SIMPSON MULLER MIXER - RIBBON EXTRUSION PRESS BATCHL}

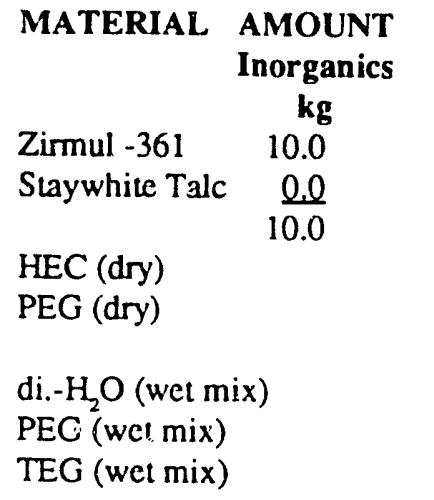

\begin{tabular}{|c|c|c|c|c|}
\hline $\begin{array}{c}\text { AMOUNT } \\
\text { Inorganics } \\
\%\end{array}$ & $\begin{array}{l}\text { AMOUNT (Dry) } \\
\text { Components } \\
\text { kg }\end{array}$ & $\begin{array}{c}\text { AMOUNT(Dry) } \\
\text { Components } \\
\%\end{array}$ & $\begin{array}{c}\text { AMOUNT } \\
\text { Total } \\
\text { kg }\end{array}$ & $\begin{array}{c}\text { AMOUNT } \\
\text { Total } \\
\%\end{array}$ \\
\hline 100.0 & 10.000 & 91.74 & 10.000 & 80.30 \\
\hline \multicolumn{5}{|l|}{$\frac{0.0}{100.0}$} \\
\hline & 0.600 & 5.51 & .600 & 4.82 \\
\hline & 0.300 & 2.75 & .300 & 2.41 \\
\hline & 10.900 & 100.00 & & \\
\hline & & & 1.311 & 10.53 \\
\hline & & & .066 & 0.53 \\
\hline & & & 175 & 1.41 \\
\hline & & & 12.452 & 100.00 \\
\hline
\end{tabular}

\section{BATCH 2}

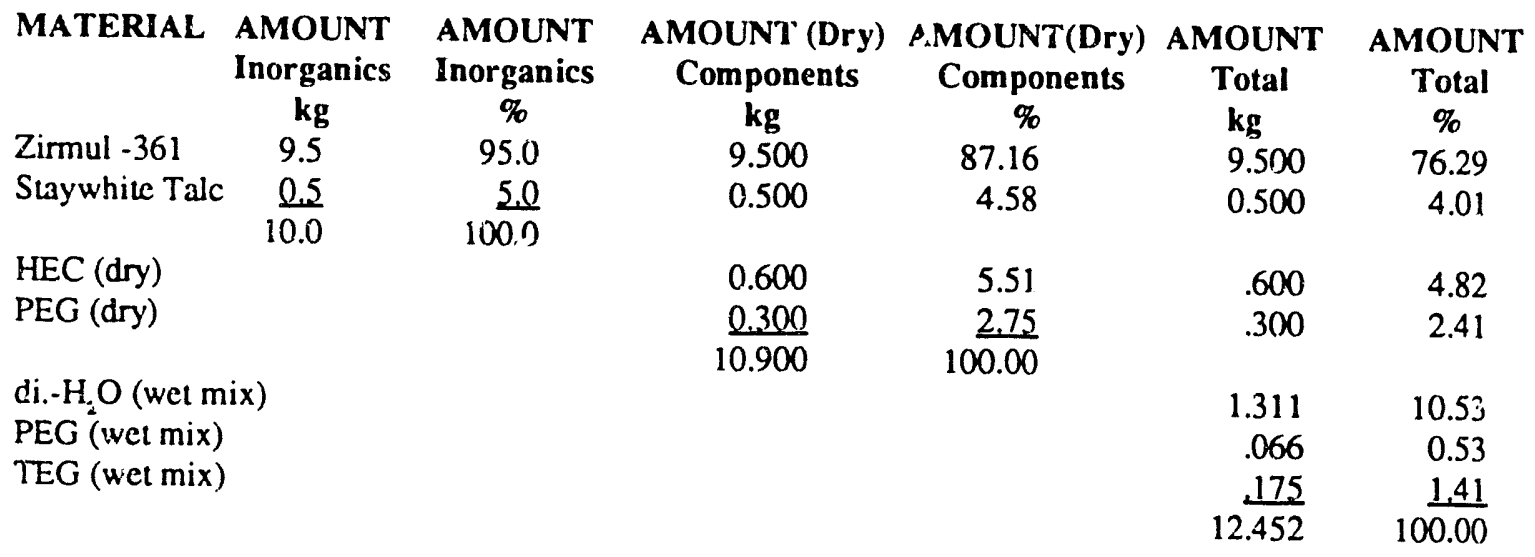

(modified wet mix. added $10 \%$ additional wet mix)

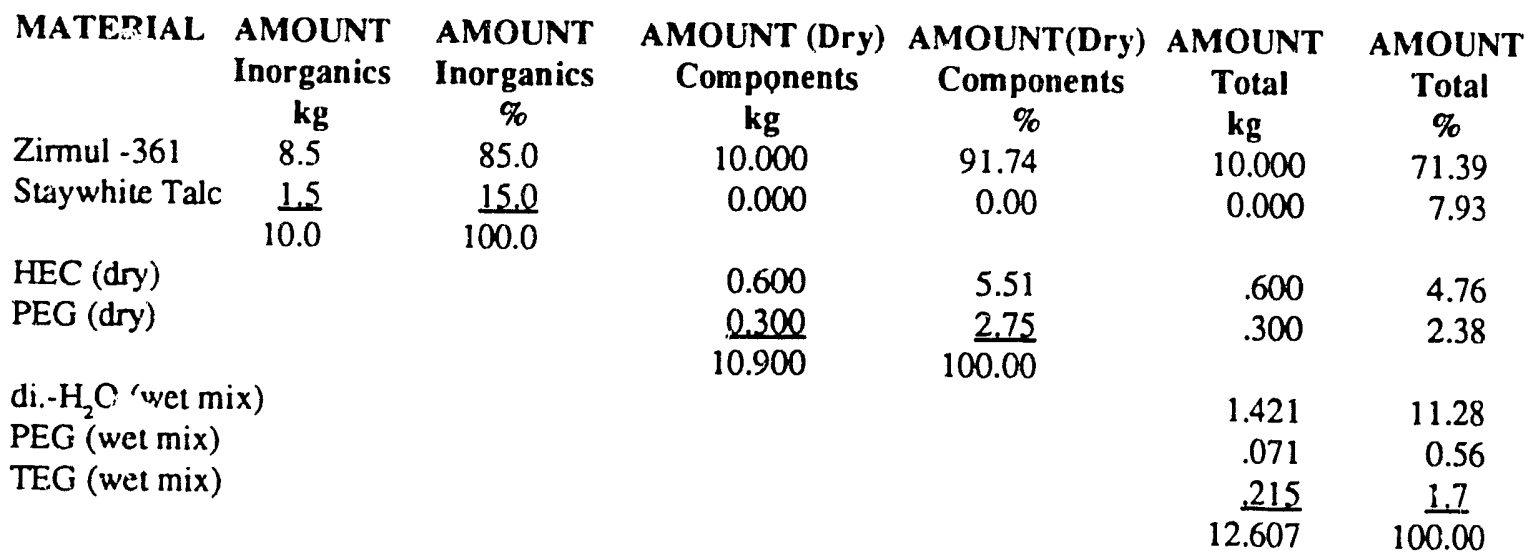


Table 9 (continued)

COMPOSITION OF COMPOUNDING TRIALS

SIMPSON MULLER MIXER - RIBBON EXTRUSION PRESS

BATCH 4

(increased the amount of drv organic binder. PEG and HEC)

$\begin{array}{lcc}\text { MATERIAL } & \begin{array}{c}\text { AMOUNT } \\ \text { Inorganics } \\ \text { kg }\end{array} & \begin{array}{c}\text { AMOUNT } \\ \text { Inorganics } \\ \text { \% }\end{array} \\ \text { Zirmul -361 } & 8.5 & 85.0 \\ \text { Stay'white Talc } & 1.5 & 15.0 \\ & 10.0 & 100.0 \\ \text { HEC (dry) } & & \\ \text { PEG (dry) } & & \\ & \\ \text { di.- } \mathrm{H}_{2} \mathrm{O} \text { (wet mix) } & \\ \text { PEG (wet mix) } & \\ \text { TEG (wet mix) } & \end{array}$

$\begin{array}{cccc}\begin{array}{c}\text { AMOUNT (Dry) } \\ \text { Components } \\ \text { kg }\end{array} & \begin{array}{c}\text { AMOUNT(Dry) } \\ \text { Components } \\ \text { \% }\end{array} & \begin{array}{c}\text { AMOUNT } \\ \text { Total } \\ \text { kg }\end{array} & \begin{array}{c}\text { AMOUNT } \\ \text { Total } \\ \text { \% }\end{array} \\ 8.500 & 77.34 & 8.500 & 66.95 \\ 1.500 & 13.65 & 1.500 & 11.81 \\ & & & \\ 0.660 & 6.01 & .660 & 5.20 \\ \underline{0.330} & 3.00 & .330 & 2.60 \\ 10.990 & 100.00 & & \\ & & 1.421 & 11.20 \\ & & .071 & 0.56 \\ & & \underline{215} & 1.68 \\ & & 12.697 & 100.00\end{array}$

\section{BATCH5}

$\begin{array}{lcc}\text { MATERIAL } & \begin{array}{c}\text { AMOUNT } \\ \text { Inorganics } \\ \mathbf{k g}\end{array} & \begin{array}{c}\text { AMOUNT } \\ \text { Inorganics } \\ \%\end{array} \\ \text { Zirmul -361 } & 8.0 & 80.0 \\ \text { Staywhite Talc } & \underline{2.0} & \underline{20.0} \\ & 10.0 & 100.0 \\ \text { HEC (dry) } & & \\ \text { PEG (dry) } & & \\ \text { di.- } \mathrm{H}_{2} \mathrm{O} \text { (wet mix) } & \\ \text { PEG (wet mix) } & \\ \text { TEG (wet mix) } & \end{array}$

\begin{tabular}{|c|c|c|c|}
\hline AMOUNT (Dry) & AMOUNT(Dry) & AMOUNT & AMOUNT \\
\hline Components & Components & Total & Total \\
\hline 8.000 & 72.79 & 8.000 & 63.01 \\
\hline 2.000 & 18.20 & 2.000 & 15.75 \\
\hline 0.660 & 6.01 & .660 & 5.20 \\
\hline 0.330 & 3.00 & .330 & 2.60 \\
\hline 10.990 & 100.00 & & \\
\hline & & 1.421 & 11.20 \\
\hline & & .071 & 0.56 \\
\hline & & 215 & 1.68 \\
\hline & & 12.697 & 100.00 \\
\hline
\end{tabular}

\section{BATCH 6}

$\begin{array}{lcc}\text { MATERIAL } & \begin{array}{c}\text { AMOUNT } \\ \text { Inorganics } \\ \text { kg }\end{array} & \begin{array}{c}\text { AMOUNT } \\ \text { 'norganics } \\ \%\end{array} \\ \text { Zirmul -361 } & 7.5 & 75.0 \\ \text { Staywhite Talc } & \underline{2.5} & \underline{25.0} \\ & 10.0 & 100.0 \\ \text { HEC (dry) } & & \\ \text { PEG (dry) } & \\ \text { di.-Hz (wet mix) } & \\ \text { PEG (wet mix) } & \\ \text { TEG (wet mix) }\end{array}$

\begin{tabular}{|c|c|c|c|}
\hline AMOUNT (Dry) & AMOUNT(Dry) & AMOUNT & AMOUNT \\
\hline $\begin{array}{l}\text { Components } \\
\text { kg }\end{array}$ & $\begin{array}{c}\text { Components } \\
\%\end{array}$ & $\begin{array}{l}\text { Total } \\
\text { kg }\end{array}$ & $\begin{array}{l}\text { Total } \\
\%\end{array}$ \\
\hline 7.500 & 68.24 & 7.500 & 59.08 \\
\hline 2.500 & 22.75 & 2.500 & 19.70 \\
\hline 0.660 & 6.01 & .660 & 5.20 \\
\hline 0.330 & 3,00 & .330 & 2.60 \\
\hline \multirow[t]{5}{*}{10.990} & 100.00 & & \\
\hline & & 1.421 & 11.20 \\
\hline & & .071 & 0.56 \\
\hline & & .215 & 1.68 \\
\hline & & 12.697 & 100.00 \\
\hline
\end{tabular}


that the mixture was homogeneous, and had a consistency similar to GTE's MAS-8400 compounded mixture (or commercially available "plastic" modeling clay).

Extrusion trials were performed on a $2.5 \mathrm{in}$. diameter manual extrusion press. The results were used to determine the base composition for a pilot scale designed experiment planned for the production sized equipment (Eirich mixer and 200T extruder). Table 8 shows the results of the extrusion test matrix. Mixing was completed when the material formed a solid ball, or the muller (Simpson) rollers began to rock. Mixing time increases as a function of the talc added. If, after 2 minutes the components appeared to be dry, additional "wet mix" was added. Table 7 illustrates the compositional changes made during the mixing. Figure 10 summarizes the compositions made, and the results of the extrusion tests. In every case the extruded material and the dried material was of acceptable quality. One reason for the increase in the required binder levels is the increased surface area associated with increased talc concentrations.

A designed experiment was formulated with a goal to optimize the composition of the organics materials added to the Z-361/Staywhite Talc mixture. An early focus on a single composition was made based upon corrosion resistance of a series of zirconia-mullite coating. placed on MAS-8400. These tests are detailed in section 2 of this report. The composition is as follows:

- $\quad 85 \%$ Zirmul - 361 (Taylor refractories)

- $15 \%$ Staywhite Talc (Cyprus Minerals)

Table 10

Extrusion Capability of Zirmul-361, Batch 1-6

$\begin{array}{ccccccccc}\text { Batch } & \text { Z-361 } & \text { Staywhite Talc } & \text { Dry PEG } & \text { Dry HEC } & \text { DiH } 0 & \text { Wet PEG } & \text { TEG } & \% \text { Z-361 in } \\ \# & \% & \% & \% & \% & \% & \% & \% & \text { Tot. Inorganics } \\ 1 & 80.31 & 0.00 & 2.41 & 4.82 & 10.52 & 0.53 & 1.41 & 100 . \\ 2 & 76.30 & 4.01 & 2.41 & 4.82 & 10.52 & 0.53 & 1.41 & 95 . \\ 3 & 71.39 & 7.93 & 2.38 & 4.76 & 11.28 & 0.56 & 1.70 & 90 . \\ 4 & 66.95 & 11.81 & 2.56 & 5.20 & 11.20 & 0.56 & 1.69 & 85 . \\ 5 & 63.01 & 15.75 & 2.56 & 5.20 & 11.20 & 0.56 & 1.69 & 80 . \\ 6 & 59.07 & 19.69 & 2.56 & 5.20 & 11.20 & 0.56 & 1.69 & 75 .\end{array}$

$\begin{array}{cccccccc}\text { Batch } & \text { Z-361 } & \text { Talc } & \% \text { Z-361 in } & \text { Calculated SA* } & \text { Mixing } & 0.25 \times 0.25 \times 2 \text { in. } & 0.050 \times .625 \times \\ \# & \% & \% & \text { Inorganics } & \mathrm{m}^{\wedge} 2 / \mathrm{g} & \text { Time }(\mathrm{m}) & \text { Bars Produced } & 4.0 \text { in. Ribbons } \\ 1 & 80.31 & 0.00 & 100 . & 5.72 & 7 & 47 & 3 \\ 2 & 76.30 & 4.01 & 95 . & 5.99 & 9 & 39 & 3 \\ 3 & 71.39 & 7.93 & 90 . & 6.26 & 12 & 33 & 3 \\ 4 & 66.95 & 11.81 & 85 . & 6.53 & 27 & 25 & 3 \\ 5 & 63.01 & 15.75 & 80 . & 6.80 & 30 & 36 & 3 \\ 6 & 59.07 & 19.69 & 75 . & 7.07 & 32 & 40 & 2\end{array}$


The selected experiment is a 16 run fractional factorial for $5,6,7$, or 8 variables. Five factors (variables) were identified, they are shown (A-E) in Table 11. The selected experimental design has all variables free of two factor interactions (they are aliased with 3 factor interactions only). Randomization of the experiment was required at all levels. The following procedures were followed to established randomization:

- Run order for experiment 1-16 was randomized

- 23 batches of Z-361 were milled. Raw materialwere extracted from each of the 23 batches (Table 12). This eliminated the effect of milling.

- The mixer was completely cleaned between runs, and $20 \mathrm{~kg}$ of a milled 30 $\mathrm{kg}$ batch of Z-361 (identical to that shown in Table 10) was blended at high speed for three minutes (to pre-coat the internal drum).

- The extruder was run at 60T. One hundred inches of material was extruded prior to making any adjustments in the die restrictions. Measurements were made on the best (flattest, tear free) 48 in. of subsequent extrusion produced.

The surface area of the designed experiment mixture is calculated (via rule of mixtures) as follows:

- $\quad$ Measured surface area of milled Z-361 blend .......5.60 $\mathrm{m}^{2} / \mathrm{g}$

- $\quad$ Measured surface area: Staywhite Talc .................11.12 $\mathrm{m}^{2} / \mathrm{g}$

- $\quad \%$ Z-361 blend in extrusion mix ..............................85\%

- $\quad \%$ Staywhite Talc in extrusion mix ........................15\%

- Calculated surface area of extrusion mix .............6.428 $\mathrm{m}^{2} / \mathrm{g}$

Results of the designed experiment are listed in Table 11. The shrinkage data reported reflects large variations in measurement capability, and is therefore, not considered reliable. The compliant nature of the extruded sheet made accurate measurement impossible with the instruments selected (calipers and micrometer). If these experiments were repeated, a profile metering device would be useful. The negative shrinkages reported result when material swells after it passes through the die cavity. Negative shrinkages may also the result of poor measurement techniques. The only response evaluated statistically was Extrusion Quality Factor (goodness). No single factor or 2 factor interactions were found to be significant at the $95 \%$ confidence level. Variable $\mathrm{C}$ was found to be a significant negative effect at the $90 \%$ confidence level. Decreasing the amount of di- $\mathrm{H}_{2} \mathrm{O}$ increases extrudability (most rejects were found to be too wet). Variable $\mathrm{C}$ was aliased with three level interactions only, (their occurrence are considered unlikely, statistically). Experiments 9 and 10 and 3 (in descending quality order) exhibited the best extrusion characteristics. 
Table 11

Compounding / Extrusion Designed Experiment

16 Experiment Fractional Factorial with 5 Variables

\begin{tabular}{|c|c|c|c|c|c|c|c|}
\hline Tariable & Variable & Lo Level & Lo Level & High Level & High Level & Nominal & Nominal \\
\hline$\frac{\#}{\mathrm{~A}}$ & $\frac{\text { Description }}{\text { di- } \mathrm{H}_{2} \mathrm{O}}$ & $\frac{\%}{90 \%}$ & 3.892 & $\frac{\%}{110 \%}$ & 4.757 & $\frac{\%}{100}$ & $\frac{\mathrm{kg}}{4.325}$ \\
\hline B & Dry PEG & $90 \%$ & 0.826 & $110 \%$ & 1.000 & 100 & 0.913 \\
\hline C & Wet PEG & $90 \%$ & 0.193 & $110 \%$ & 0.236 & 100 & 0.2145 \\
\hline D & TEG & $90 \%$ & 0.549 & $110 \%$ & 0.671 & 100 & 0.610 \\
\hline$E$ & Dry HEC & $90 \%$ & 1.652 & $110 \%$ & 2.019 & 100 & 1.836 \\
\hline
\end{tabular}

\section{Design Matrix}

\begin{tabular}{cccccc} 
Experiment & $\underline{A}$ & $\underline{B}$ & $\underline{C}$ & $\underline{D}$ & E \\
\hline 1 & - & - & - & + & + \\
2 & + & - & - & - & - \\
3 & - & + & - & - & + \\
4 & + & + & - & + & - \\
5 & - & - & + & + & - \\
6 & + & - & + & - & + \\
7 & - & + & + & - & - \\
8 & + & + & + & + & + \\
9 & + & + & + & - & - \\
10 & - & + & + & + & + \\
11 & + & - & + & + & - \\
12 & - & - & + & - & + \\
13 & + & + & - & - & + \\
14 & - & + & - & + & - \\
15 & + & - & - & + & + \\
16 & - & - & - & - & -
\end{tabular}

\section{Example of Batch Compositions (Extracted from design matrix)}

\begin{tabular}{|c|c|c|c|c|c|c|c|}
\hline \multirow[t]{3}{*}{$\begin{array}{l}\text { Variable } \\
\text { Name }\end{array}$} & $\begin{array}{c}\text { Material } \\
\text { Description }\end{array}$ & $\begin{array}{c}\text { Batch } 1 \\
\mathrm{~kg}\end{array}$ & $\begin{array}{c}\text { Batch } 1 \\
\%\end{array}$ & $\begin{array}{c}\text { Batch } 8 \\
\mathrm{~kg}\end{array}$ & $\begin{array}{c}\text { Batch } 8 \\
\%\end{array}$ & $\begin{array}{c}\text { Batch } 16 \\
\mathrm{~kg}\end{array}$ & $\begin{array}{c}\text { Batch } 16 \\
\%\end{array}$ \\
\hline & $\mathrm{Z}-361$ & 23.654 & 66.73 & 23.654 & 64.74 & 23.654 & 67.66 \\
\hline & Staywhite Talc & 4.192 & 11.83 & 4.192 & 11.47 & 4.192 & 11.99 \\
\hline $\mathrm{E}$ & Dry HEC & 2.019 & 5.70 & 2.019 & 5.53 & 1.652 & 4.73 \\
\hline B & Dry PEG & 0.826 & 2.33 & 1.000 & 2.76 & 0.826 & 2.36 \\
\hline A & $\mathrm{di}-\mathrm{H}_{2} \mathrm{O}$ & 3.892 & 10.98 & 4.757 & 13.02 & 3.892 & 11.13 \\
\hline $\mathrm{C}$ & Wet PEG & 0.193 & 0.54 & 0.236 & 0.65 & 0.193 & 0.55 \\
\hline D & TEG & $\underline{0.671}$ & 1.89 & $\underline{0.671}$ & $\underline{1.84}$ & $\underline{0.549}$ & 1.57 \\
\hline & & 35.477 & 100.00 & 36.538 & 100.00 & 34.958 & 100.00 \\
\hline
\end{tabular}




\section{Table 11 (continued) \\ Compounding / Extrusion Designed Experiment}

16 Experiment Fractional Factorial with 5 Variables

\begin{tabular}{|c|c|c|c|}
\hline \multicolumn{4}{|c|}{ Aliases } \\
\hline Variable & Nominal & Factor & \\
\hline$\#$ & Description & $\mathrm{kg}$ & Aliases \\
\hline A & $\mathrm{di}-\mathrm{H}_{2} \mathrm{O}$ & 4.325 & 3-Factor only \\
\hline B & Dry PEG & 0.913 & 3-Factor only \\
\hline $\mathrm{C}$ & Wet PEG & 0.2145 & 3-Factor only \\
\hline D & TEG & 0.610 & 3-Factor only \\
\hline $\mathrm{E}$ & Dry HEC & 1.836 & 3-Factor only \\
\hline
\end{tabular}

\section{Responses Measured}

RESPONSE

\%SHRINKAGE: RIB WIDTH \%SHRINKAGE: THICKNESS \%SHRINKAGE:LENGTH

EXTRUDABILITY
MEASURE

EXTRUDED RIB WIDTH \& DRY RIB WIDTH DIE GAP FOR SHEET \& DRY THICKNESS CUT LENGTH AND SHRINKAGE LENGTH QUALITATIVE MEASURE (1=GOOD, 5=POOR)

\subsubsection{Binder Removal and Sintering of Z-1000}

Extruded samples (sheets) were cut, air dried, oven dried and stacked as described in 2.2.1 (steps 15-20): Dried sheets were measured (shrinkages were recorded in Table 13). Extruded sheets from test 3, 9, and 10 were placed into a standard MAS-8400 binder fire / sintering/annealing (process step \#24 in section 2.2.1) and processed along side of a 600 pound load of production ceramic recuperator matrix elements. The sintering cycle called for a final temperature of $2525^{\circ} \mathrm{F}$, a temperature well below that required to fully react the Inorganic materials. No cracking was observed on the sintered sheets. Those sheets stacked in contact with and normal to one another showed evidence of bonding to each other, despite the fact that no additional inorganic material was placed at the interface. Shrinkage of the presintered material was measured in the 12-13\% range. Individual sheets and bonded matrix sections (46 plate-fin sections high) were then divided into three groups. Three sintering runs were then run to temperatures of 2642,2777 , and $2912^{\circ} \mathrm{F}\left(1450,1525\right.$, and $\left.1600^{\circ} \mathrm{C}\right)$. Ramp rates were $90 \mathrm{~F} / \mathrm{h}$ to the soak temperature, and the soak temperature was held for 4 hours. Programmed cooling rates were $100 \mathrm{~F} / \mathrm{h}$ to room temperature (however actual cooling rates were much slower below $800^{\circ} \mathrm{F}$ ). Visual inspection showed that regardless of sintering temperature, no cracking was evident. 


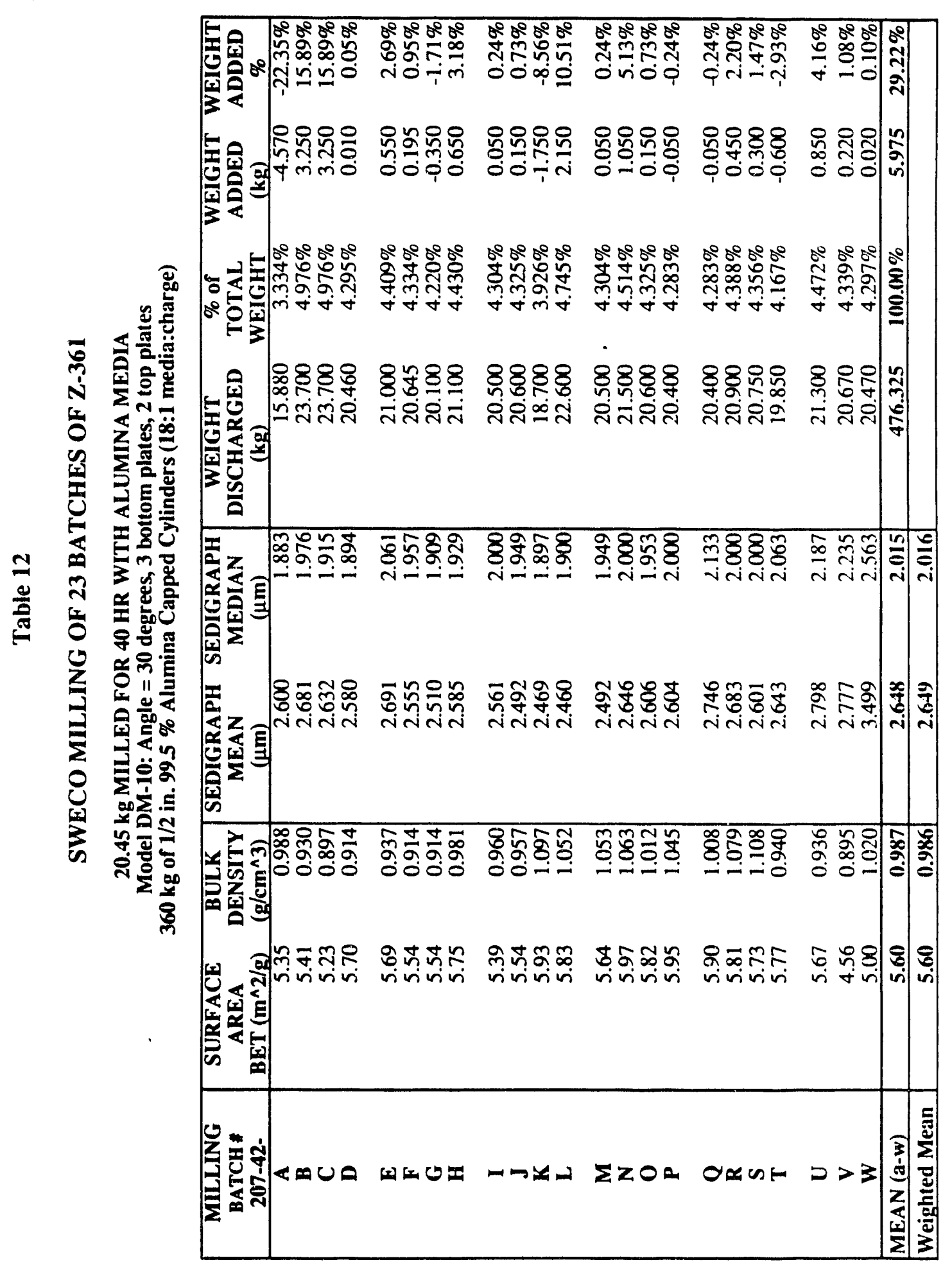




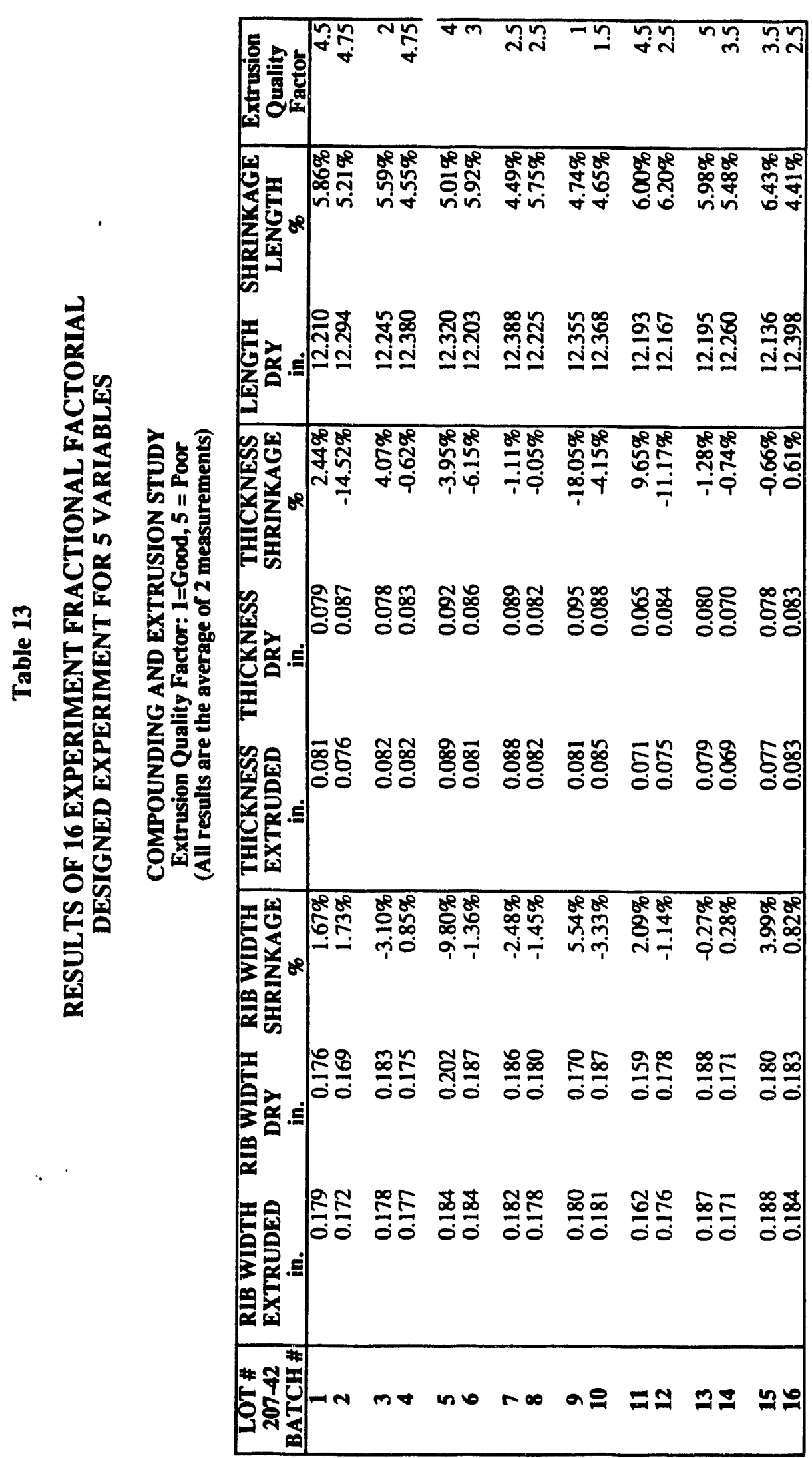




\subsubsection{Physical Properties of Z-1000}

Thermal expansion, flexural strength (transverse rupture), and porosity (via mercury porosimeter) was measured for the material sintered at $2777^{\circ} \mathrm{F}$ as shown in Table 14 . A micrograph of the material is shown in Figure 16.

Table 14

Properties of Z-1000 (85\% milled Zirmul-361, 15\% Talc)

Sintered at $2777^{\circ} \mathrm{F}$.

Thermal Expansion $4.8 \times 10^{.6} /{ }^{\circ} \mathrm{F}\left(\mathrm{RT}-800^{\circ} \mathrm{F}\right)$

Modules of Rupture (4 pt.) $24.4 \mathrm{Ksi}(\sigma=4.2)$

Porosity $16 \%$

(range .003-180 $\mu \mathrm{m}$ )
$90 \%<180 . \mu \mathrm{m}$
$80 \%<40 . \mu \mathrm{m}$
$75 \%<.02 \mu \mathrm{m}$
$50 \%<.015 \mu \mathrm{m}$
$10 \%<.01 \mu \mathrm{m}$

Phase Content

Major $\mathrm{Al}_{2} \mathrm{O}_{3} \quad$ Corundum

Major $\mathrm{Al}_{6} \mathrm{Si}_{2} \mathrm{O}_{13}$ Mullite

Minor $\mathrm{ZrSiO}_{4}$ Zircon Minor $\mathrm{ZrO}_{2}$ Baddeleyite

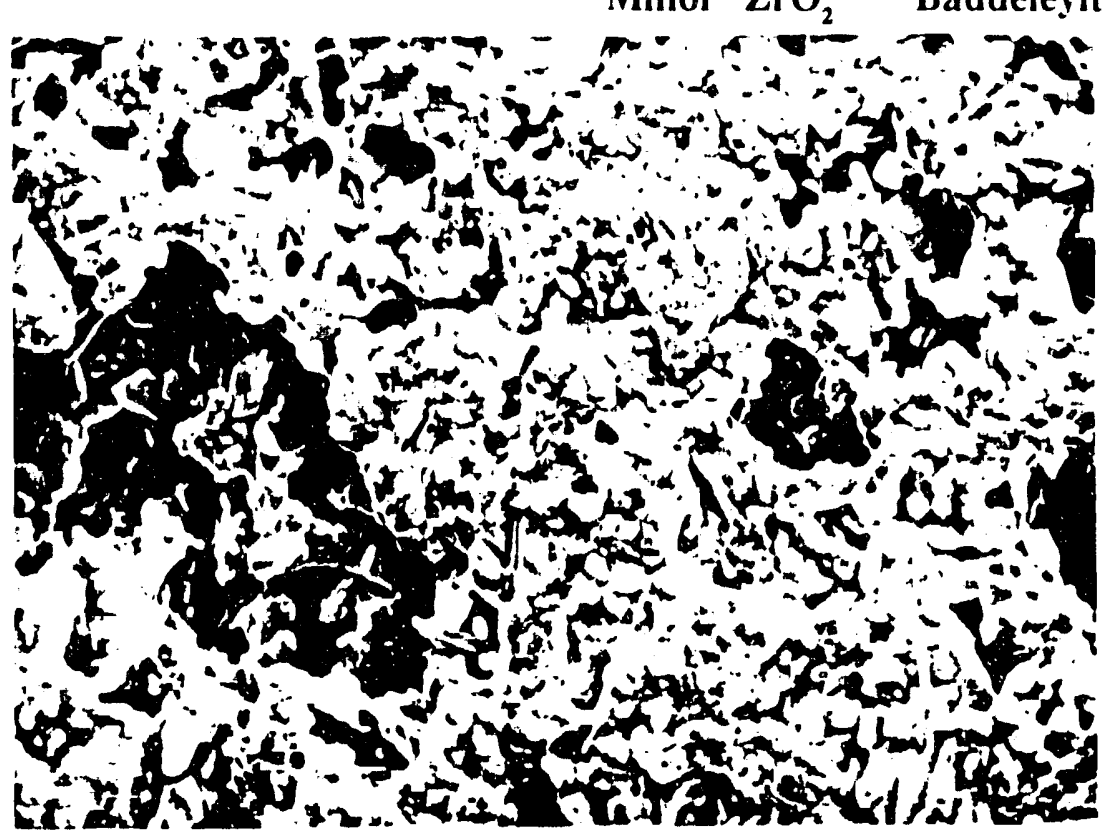

Figure 16

Micrograph of Z-1000 (85\% milled Zirmul-361, 15\% Talc) Sintered at $2777^{\circ} \mathrm{F}, 1000 \mathrm{x}$ 
Strength measurements (modulus of rupure) were performed using 4 point loading with inner and outer loading spans of $0.4 \mathrm{in} .(10.16 \mathrm{~mm})$ and $0.9 \mathrm{in}$. $(22.86 \mathrm{~mm})$ respectively. Load was applied using " knife edges" in the form of cylindrical rods $0.25 \mathrm{in} .(6.35 \mathrm{~mm})$ in diameter made from hot pressed $\mathrm{SiC}$. The self aligning fixture used for testing is illustrated in Figure 17. A schematic of the loading arrangement is shown in Figure 18. The test specimens used were rectangular bars of length $1.2+/-0.05 \mathrm{in}$. (30.5mm), width $0.1+/-0.0005 \mathrm{in}$. $(2.54 \mathrm{~mm})$, and thickness $0.05+/-0.0005$ in. $(1.27 \mathrm{~mm})$. Opposing faces of the bars were ground flat and parallel within $0.005 \mathrm{in}$. and were chamfered $0.006+/-0.002$ in. at $45^{\circ}$ as illustrated in Figure 19. Testing was performed using a Tinius Olsen universal testing machine with DS-30 computer control. Test samples were aligned in the fixture and then were loaded to failure at a crosshead speed of $0.05 \mathrm{in}$./minute. Modulus of rupture was calculated from the following expression;

$$
\mathrm{S}_{\text {mor }}=1.5 \mathrm{~L}(\mathrm{~J}-\mathrm{I}) /\left(\mathrm{wt}^{2}\right)
$$

where

$\mathrm{S}_{\operatorname{mor}}=$ Maximum outer fiber tensile stress of test specimen at fracture (psi)

$\mathrm{L}=$ Load at fracture (pounds)

$\mathrm{J}=$ Outer loading span (in.)

$\mathrm{I}=$ Inner loading span (in.)

w = Width of bar (in.)

$\mathrm{t} \quad=$ Thickness of bar (in.)

The modulus of rupture was measured for 10 samples. A mean fracture strength of 24.4 ksi $(\sigma=4.2)$ was calculated. The data was not considered reliable due to the distributed porosity identified in the microstructural analysis. By comparison MAS- 8400 has a strength of $8.5 \mathrm{Ksi}$. The sample number was considered too small to include Weibull statistics, as $n>25$ are generally required for this measure. The large standard deviation is typical of a material with a large pore fraction, and has been observed in data obtained from other compositions fabricated with this binder system. The distributed porosity is not considered detrimental for this application, in that it has been shown to increase the thermal shock resistance (TSR), despite its obvious negative impact on fracture strength. One explanation for this observation may be that the distributed porosity also decreases the elastic modulus (which would increase TSR). A dry press and sinter fabrication technique that yielded a part with negligible porosity would be required to determine the "intrinsic" strength of this material. No attempt was made to determine the strength of a "fully dense" Zirmul-361:Talc (85:15) blend. 


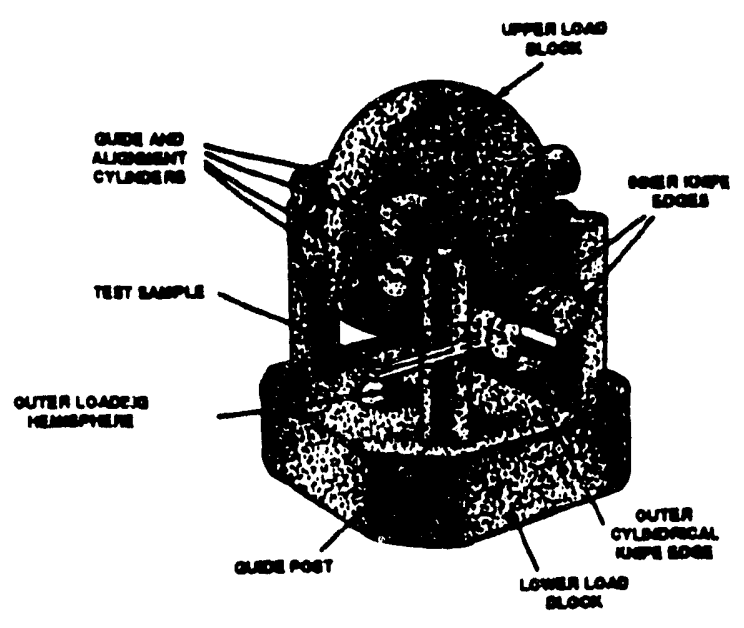

Figure 17

Modulus of Rupture Loading Fixture
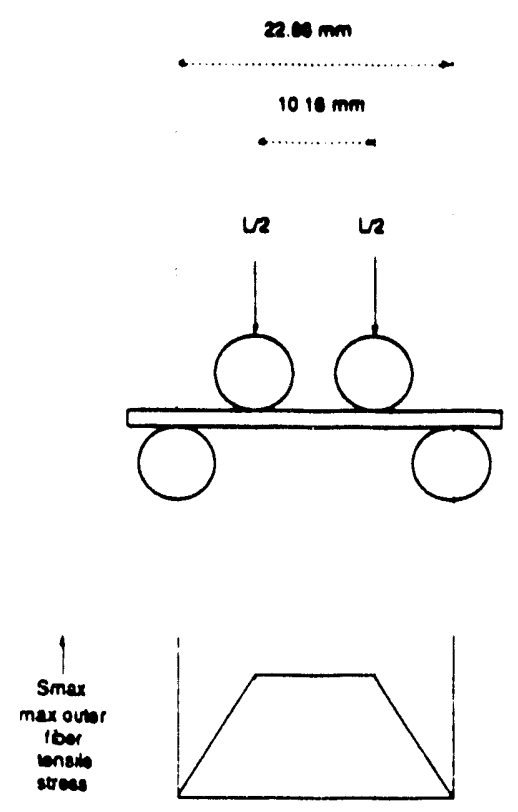

Figure 18

Four Point Bend Test Loading Arrangement 

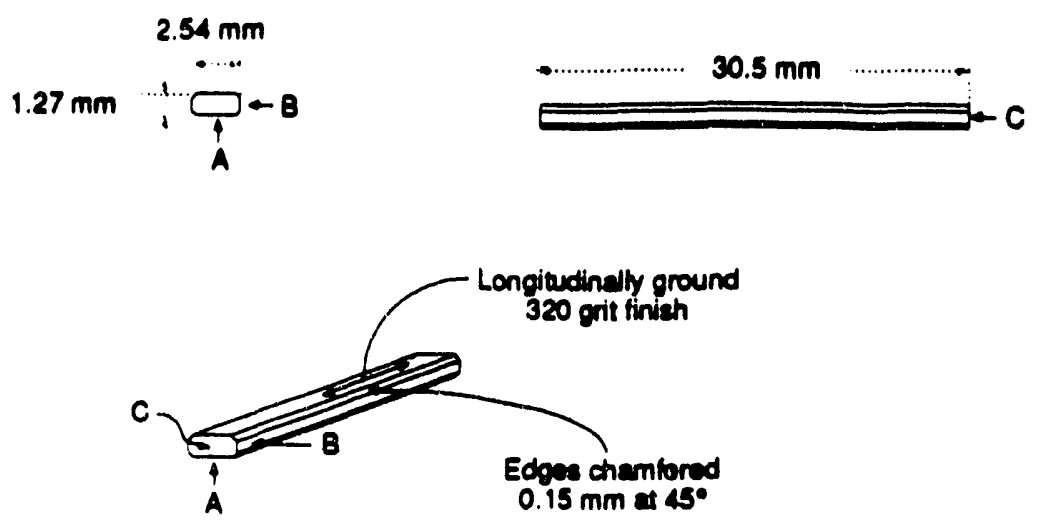

Figure 19

\section{Modulus of Rupture Test Specimen}

Phase content of the sintered Zirmul-361:Talc (85:15) material was determined for samples fired at 2642,2777 , and $2912^{\circ} \mathrm{F}$. No differences in the phases present were observed, with the exception of the presence of an unidentified phase found only in the material sintered at $2642^{\circ} \mathrm{F}$. This is probably a remnant : of the talc raw material. The diffraction patterns were done on a Rigaku (USA Inc.) Model D/Max Geigerflex. Phase identification and data reduction was done with the aid of the Rigaku "Peak Finding and Search/Match" software programs run on a DEC PDP-11/23 plus computer. The data base of reference diffraction patterns of the JCPDS - International Center for Diffraction Data was searched. The following phases were identified:

- $\mathrm{Al}_{2} \mathrm{O}_{3}$ Corundum PDF\#10-173"

- $\mathrm{Al}_{6} \mathrm{Si}_{2} \mathrm{O}_{13}$

- $\mathrm{ZrSiO}_{4}$

- $\mathrm{ZrO}_{2}$

- unknown

- $\mathrm{SiO}_{2}$ or $\mathrm{ZrO}_{2}$

Mullite PDF\#15-776

Zircon

Baddeleyite

PDF\#6-266 a peak was found @ $19^{\circ}$ that is unidentified $\left(2642^{\circ} \mathrm{F}\right.$ sinter only) a peak was found @ 30.2 ${ }^{\circ}$ that may be either

The diffraction patterns are shown in Figure 20.

* $\quad$ Powder Diffraction File \# (PDF\#) 


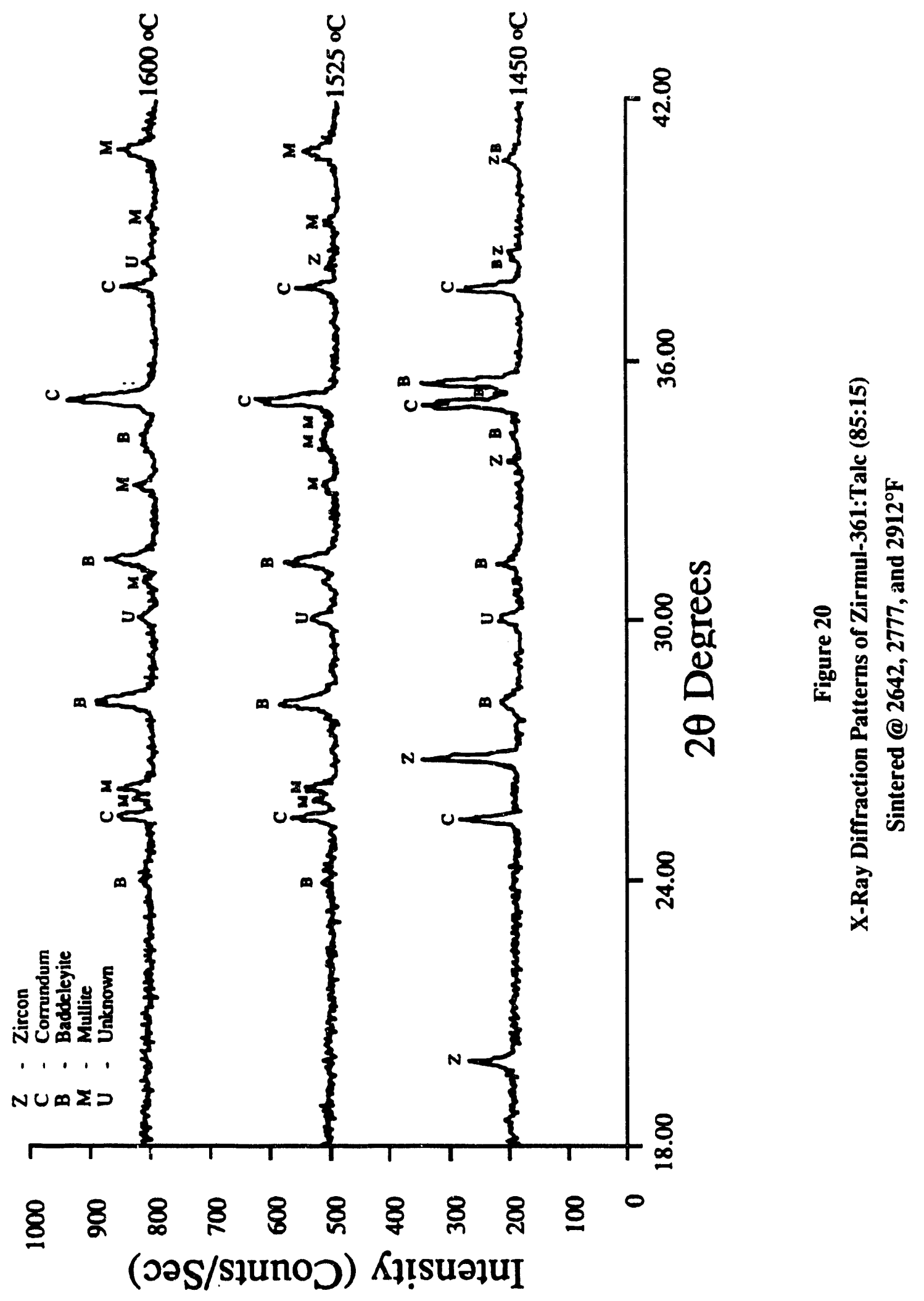




\subsubsection{Crossflow Recuperator Design for Z-1000 Material}

Figure 21 illustrates the anticipated design of a recuperator incorporating a Z-1000 matrix. The low thermal shock resistance of Z-1000 (compared to MAS-8400) necessitates the reduction (minimization) of thermal stresses across the ceramic. The preheated air is counter-flowed with respect to the exhaust gas flow. A design that calls for preheat air temperatures to increase dramatically in the first two passes is anticipated. Surface area (small cell size) and passage free flow area will be selected to maximize differential temperatures between the exhaust gas and the preheated air temperature in pass 1 and 2 , and minimize differential temperatures in the third pass. Exhaust gases exiting the third pass $(\mathrm{Z}-1000)$ module can mix prior to entry into the MAS- 8400 matrix. The design concept shown in the figure has been demonstrated with sectioned MAS- 8400 recuperators, and offers merit for use in GTE's standard product, as thermal stresses on a single matrix are extreme during transient conditions found in many industrial applications (when a furnace door opens a matrix cools rapidly, as exhaust gas flow rates drop by $50-90 \%$, when the door closes it is stressed again until equilibrium conditions return). No attempt to develop the technology necessary to bond crossflow sheets (plate-fin) together was made during this contract effort. Therefore the aforementioned design has not been tested with Z-1000. Additionally, the corrosion resistance of a monolithic sample has not been evaluated on the GTE test stand, or in the field.

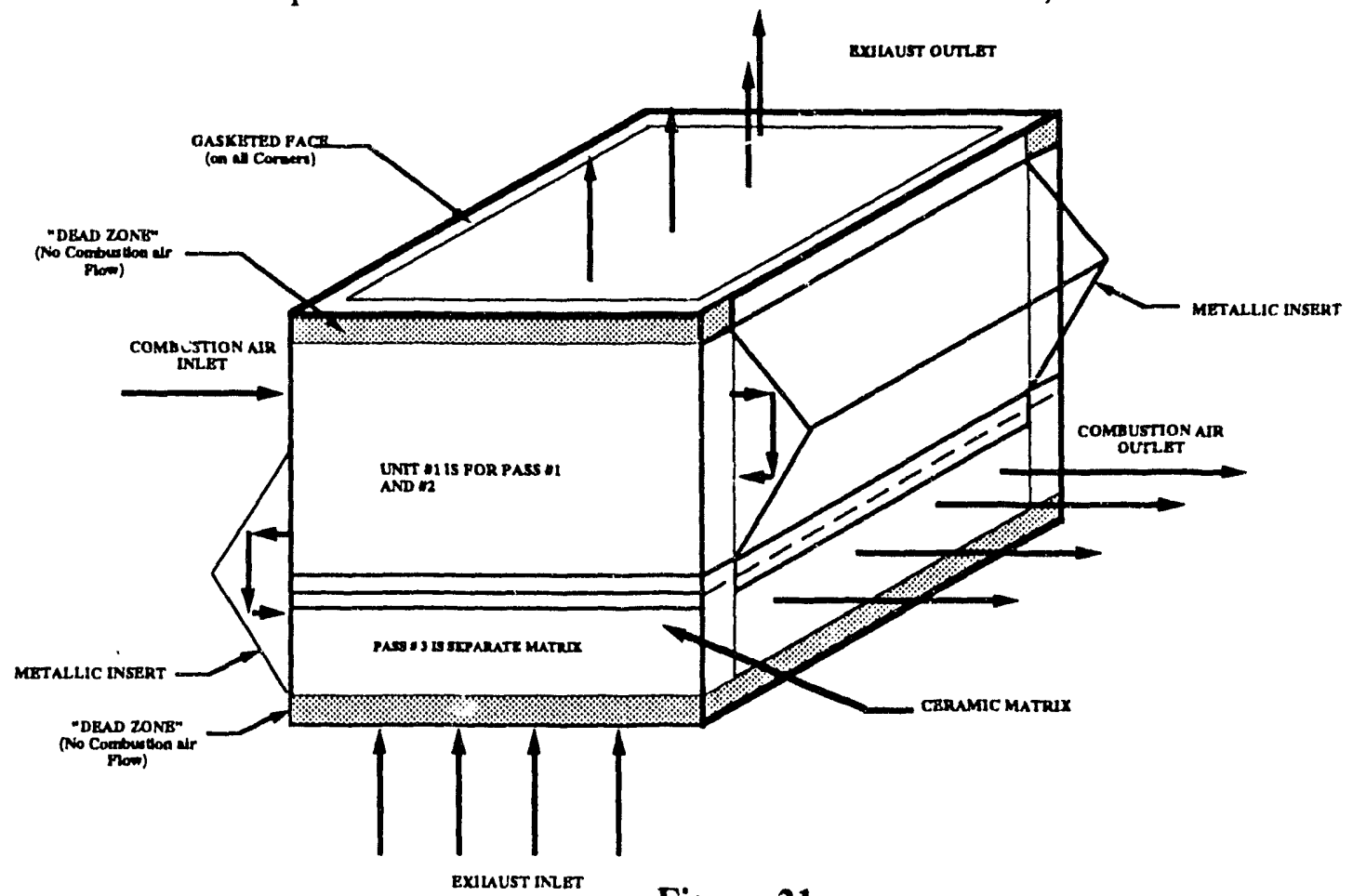

Figure 21

Segmented Recuperator Design for a Z-1000 Ceramic Matrix 


\section{CONCLUSIONS}

The following conclusions can be drawn from the contract effort:

- A GTE Model R1500 recuperator was exposed to sufficient $\mathrm{NaOH}$ at elevated temperature to destroy it in $6 \mathrm{~h}$. An analysis of the unit determined its mode of failure was identical to a recuperator that failed from long term alkali attack. This attack was duplicated on a recuperator corrosion test stand fabricated at GTE. The recuperator test stand could expose up to 3 small test samples ( $3 \times 3 \times 3$ in.) to contaminants.

- A corrosion resistance test method has been established that enables a potential ceramic material to be screened for resistance to high temperature attack $\left(2450^{\circ} \mathrm{F}\right)$ of alkali's and lead. The test requires that the test material adhere to MAS-8400 (cordierite).

- A zirconia-mullite mixed oxide ceramic was found to resist alkali attack during a $6 \mathrm{~h}$ exposure to $\mathrm{PbO}$ and $\mathrm{NaOH} @ 2450^{\circ} \mathrm{F}$. The same test melted a MAS- 8400 substrate. The best protection was afforded by a sintered composition manufactured with $85 \%$ Zirmul-361 and $15 \%$ Staywhite Talc. The Z-361 was milled in $\mathrm{Al}_{2} \mathrm{O}_{3}$ to obtain a surface area of approximately 5.5 $\mathrm{m}^{\wedge} 2 / \mathrm{g}$. The mixture was fired to $2777^{\circ} \mathrm{F}$, then applied to a MAS -8400 substrate and fired to $2500^{\circ} \mathrm{F}$.

- Thin coatings of materials to be evaluated were found to be least likely to spall off during a test.

- A process capable of manufacturing thin wall (plate-fin) shapes of Z-1000 (zirconia-mullite mixed oxide) was developed. The methodology used to develop the process was the bench-marking of the MAS- 8400 recuperator matrix production process.

- Plate fin shapes were successfully dewaxed and sintered to three temperatures $\left(2642,2777\right.$, and $\left.2912^{\circ} \mathrm{F}\right)$. Phases present were determined. Strength, of the material was $24.4 \mathrm{ksi}$. Porosity is in the $13.5 \%$ range. Major phases idencified include mullite, zircon, baddeleyite, and corundum.

- A ceramic recuperator can be manufactured with a segregated matrix. The corrosion resistant portion can be placed in an area that requires corrosion resistance, but minimizes the need for thermal shock resistance. This design concept was successfully tested by GTE (GTE func'ed).

- The encouraging performance of the Z-1000 indicates that the technology necessary to manufacture a crossflow matrix should be developed. 
- A matrix of Z-1000 should be manufactured and tested on the corrosion test stand, GTE's recuperator test furnace and then field tested.

\section{REFERENCES}

1. Cleveland J.J., et al, Ceramic Heat Recuperators for Industrial Heat Recovery, Final Report , No. DOE/EC/02162, August 1980.

2. Dorazio, R.E., et al, The GTE Ceramic Recuperator for High Temperature Waste Heat Recovery, 1984 Industrial Energy Conservation Technology Conference, Houston, TX, April 15-18, 1984.

3. Gonzalez, J.M., Ferri, J.L., and Rebello,W.J., Indisstrial Operating Experienceof the GTE Ceramic Recuperator, Final Report, ORNL/Sub/86-22044, June 1990.

4. Ally, M.R., et al, Optimization of Multi-pas: Crossflow Heat Exchangers for Waste Heat Recovery Applications, 1984 National Heat Transfer Conference, Niagara Falls, N.Y., August 5-8, 1984.

5. Ferri, J.L., Temperature Compensated Air/Fuel Ratio Control on a Recuperated Furnace, 1983 Industrial Energy Conservation Technology Conference, Houston, TX, April $17-$ 26, 1983.

6. Gonzalez J.M., and W. J. Rebello, Eurnace Controls using High Temperature Preheated Combustion Air, 1981 Industrial Energy Conservation Technology Conference, Houston, TX, April 26-29, 1981.

7. Dorazio, R. E., et al, Technology Acceleration Program for the GTE Ceramic High Temperature Recuperator, Final Report, Contract No. DE-FC01-80CS 40330, January 1983. 
1-2. Central Research Library

3. Document Reference Section

4-5. Laboratory Records Department

6. Laboratory Records, ORNL RC

7. ORNL Patent Section

8-10. M\&C Records Office

11. R. A. Bradley

12. R. S. Carlsmith

13. J. H. DeVan

14. J. R. DiStefano

15. J. I. Federer

16-41. M. A. Karnitz
42. J. R. Keiser

43. E. L. Long

44. Y. A. Chang, Consultant

45. H. W. Fogleson, Consultant

46. J. J. Hren, Consultant

47. M. L. Savitz, Consultant

48. J. G. Simon, Consultant

49. K. E. Spear, Consultant

EXTERNAL DISTRIBUTION

50-51. GTE PRODUCTS CORPORATION, Hawes Street, Towanda, PA 18848
J. L. Ferri
J. Gonzalez

52-54. IDAHO NATIONAL ENGINEERING LABORATORY, P. O. Box 1625, Idaho Falls, ID 83415

B. W. Brown

W. R. Lloyd

W. G. Reuter

55. PAR ENTERPRISE, INC., 12601 Clifton Hunt Lane, Clifton, VA 22024

W. J. Rebello

56. PENNSYLVANIA STATE UNIVERSITY, 201 Steidle Building, University Park, PA 16801

R. E. Tressler 
57-59. SOLAR TURBINES INCORPORATED, P. O. Box 85376, San Diego, CA 92138-5376
B. Harkins
M. Van Roode
M. E. Ward

60-62. STONE \& WEBSTER ENGINEERING CORPORATION, 245 Summer Street, Boston MA 02107
L. J. McDonough
R. A. Rosenberg
J. J. Williams

63. UNIVERSITY OF TENNESSEE SPACE INSTITUTE (UTSI), MS 3, Tullahoma, TN 37388

W. H. Boss

64. U.S. DOE, OAK RIDGE OPERATIONS OFFICE, P. O. Box 2008, Building 4500N, MS 6269, Oak Ridge, TN 37831
G. L. Riner
Program Manager

65-67. U.S. DOE, OFFICE OF INDUSTRIAL TECHNOLOGIES, 1000 Indeperdence Avenue, Forrestal Building, Washington, DC 20585
J. Eustis
W. P. Parks, Jr.
S. L. Richlen

68. U.S. DOE, OAK RIDGE OPERATIONS OFFICE, P. O. Box 2001, Oak Ridge, TN $37831-8600$

Office of Assistant Manager of Energy Research and Development

69-78. U.S. DOE, OFFICE OF SCIENTIFIC AND TECHNICAL INFORMATION, P. O. Box 62, Oak Ridge, TN 37831

For distribution by microfiche as shown in DOE/OSTI-4500, Distribution Category UC-310 Industrial Programs (General) 

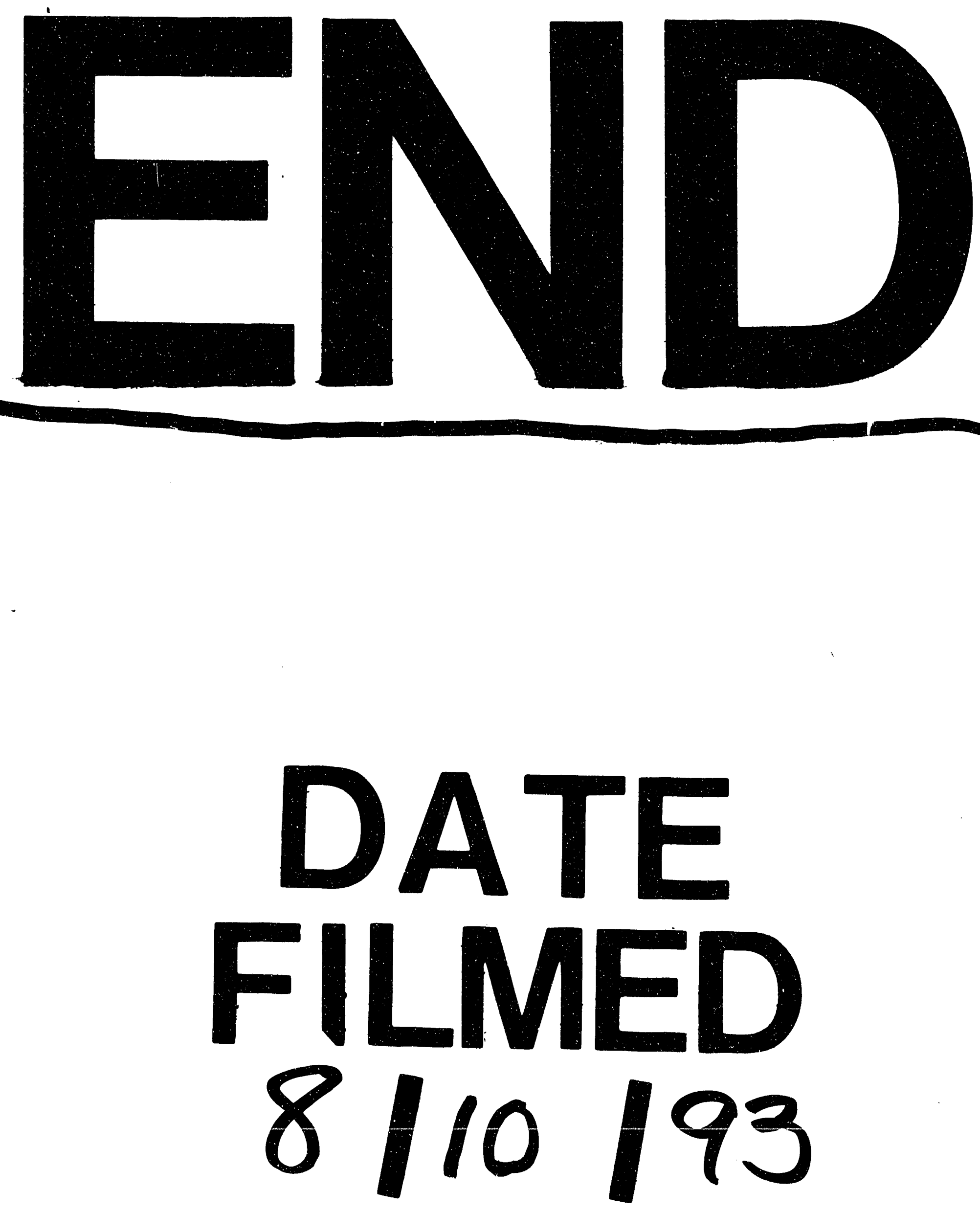
